\title{
Monitoring Water Quality of Some Canals in Delta Region, Egypt
}

\author{
Sabry A. Abdallah ${ }^{*}$, Hassan R. El-Ramady ${ }^{2}$, Abdelhakeem E. El-Sherbeni', \\ Helmy A. Anber ${ }^{1}$, Elsayed A. Kishk ${ }^{1}$, Sobhy Hamed ${ }^{1}$ and Hazem M. Amine ${ }^{1}$ \\ ${ }^{1}$ Plant Protection Dept., Faculty of Agriculture, Tanta University, Egypt. \\ ${ }^{2}$ Soil and Water Dept., Faculty of Agriculture, Kafrelsheikh University, Egypt.
}

\begin{abstract}
口 GYPT suffers from the scarcity of water resources. The problem has been exacerbated

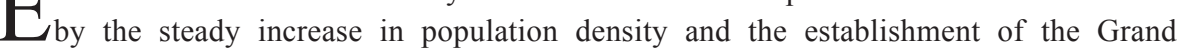
Ethiopian Renaissance Dam. Therefore, preserving the availability and quality of this resource is enormously important. Water quality is affected by a number of factors related to the characteristics of the watercourse and surrounding environment, like soil type, agricultural and industrial activity in the studied regions. Therefore, a comparative study was conducted on water samples collected from eight different locations at west and middle Delta regions from Beheira and Gharbia governorates. The obtained results showed that there are significant differences among the means of sample collection sites and dates, as well as the interaction between studied variables in all studied parameters. Although, most physical and chemical parameters were within standards limits except turbidity and chemical oxygen demand (COD). However, the average values of turbidity, color and $\mathrm{pH}$ were convergent in both governorates. While total dissolved salts (TSS) had a higher value $\left(42.2 \mathrm{mg} \mathrm{L}^{-1}\right)$ in the Beheira governorate. In the case of, the remaining studied parameters, the values recorded in Gharbia gov. were higher than the corresponding values recorded in Beheira gov. including $\mathrm{COD}$ and $\mathrm{UV}_{245}$ absorbance, which are associated with organic pollution. Thus, physical and chemical approaches can be used to evaluate the water quality in relevant locations. Further studies based on biological approaches should be also carried out.
\end{abstract}

Keywords: Water quality, Surface water, Physical and chemical parameters, Nile Delta.

\section{Introduction}

It is well known that Egypt as an African country suffers from arid conditions. Egypt also has a very rapid growth rate in its population, which drives water demand beyond its annual constant supply (Wahba et al. 2018). In recent years, there has been an increasing interest in a water crisis in Egypt (Negm 2019). Concerning the main sources of water in Egypt, these sources include rainfall (1.18\%), underground sources (9.03\%) and the Nile River as the main reliable source of water (CAPMAS 2017). Therefore, there is a decrease in the total water per capita in Egypt from $2041 \mathrm{~m}^{3}$ in 1962 to $637 \mathrm{~m}^{3}$ in 2014 (FAO 2017). Thus, Egypt suffers from high and chronic water scarcity level, which may negatively affect general well-being, human health and may restrict the ability to accomplish economic development (Wahba et al. 2018).
Due to the lack of water resources in Egypt, the Ministry of Water Resources and Irrigation has resorted to increasing the use of groundwater and reuse of waste-water in irrigation of newly reclaimed areas (Salman et al. 2019). The water quality depends on a number of factors, which divided into those related to the watercourse itself and the other related to the surrounding environment. Although both west and middle delta regions derive their water from the Rosetta branch, they differ in many characteristics such as soil type, irrigation system, and type of plantation, etc. These factors found to be influencing water quality, have been explored in several studies. A considerable amount of literature has been published on the water in Egypt and its quality. These studies include many topics such as the pollution of groundwater in Egypt (e.g., Omran 2017; Salman et al. 2019)and water quality assessment (e.g., Abdel-Satar et al. 2017; Salem

*Corresponding author e-mail: sabry.abdelaal@agr.tanta.edu.eg DOI: 10.21608/JENVBS.2019.11428.1057

(C)2019 National Information and Documentation Center (NIDOC) 
et al. 2019).

The present study hypothesized that the environmental factors have a great influence on the water quality in watercourses. So, it studied two adjacent areas, derive their water from the same source and they differ in several environmental characteristics with an attempt to find the relationship between the water quality and those environmental characteristics.

\section{Materials and Methods}

\section{Study area and sampling sites}

Water samples were monthly collected from March 2014 to February 2015. The samples collected from the west and middle Delta regions (Beheira and Gharbia governorate, respectively). Four locations from each governorate were selected to collect water samples.ConcerningGharbia, locations included Mit-Hebeish Al Bahreyah, Nafya and Mahalat Menouf (along El-Kased canal) and also from Achenawai (from Sobtaas canal, which is a branch of El-Kased canal). Also, water samples collected from four sites in Beheira included Shubra Oseim, Al Tairyyah and Alqam (along with the Behery Rayah) and Markaz Badr (at Nassery Rayah, which is a branch from BeheryRayah). The names of the sampling sites and their detailed description, as well as the latitude and longitude, are presented in Table 1 and Fig. 1. The two study regions had significant environmental and geographic differences between them. The studied region in the Gharbia is characterized by clay soil. The main cultivated crops are wheat, clover, corn, rice, potatoes, beans, and some vegetables. Irrigation water is applied by the traditional method of flooding, the irrigation system consists of canals and the drainage water is collected in open drains. the region had some subsurface drains (Table 2). In contrast, the soil texture is sandy in the studied region of Beheira. Bananas, strawberries, citrus fruits, grapes and potatoes, peanuts are the main agricultural crops with some areas cultivated with maize, wheat, and alfalfa. The drip irrigation system is the most widely used in the region (except Shubra Oseim, which depends on surface irrigation), Also the region had some subsurface drains. However, almost $50 \%$ of the lands are cultivated by Bananas. Banana is a tree-like perennial herb, with high water and fertilizer requirements. It cultivated every five years. Due to the high economic value of various crops in Beheira, it is noted excessive use of chemical fertilizers, pesticides, and other

Env. Biodiv. Soil Security Vol. 3 (2019)

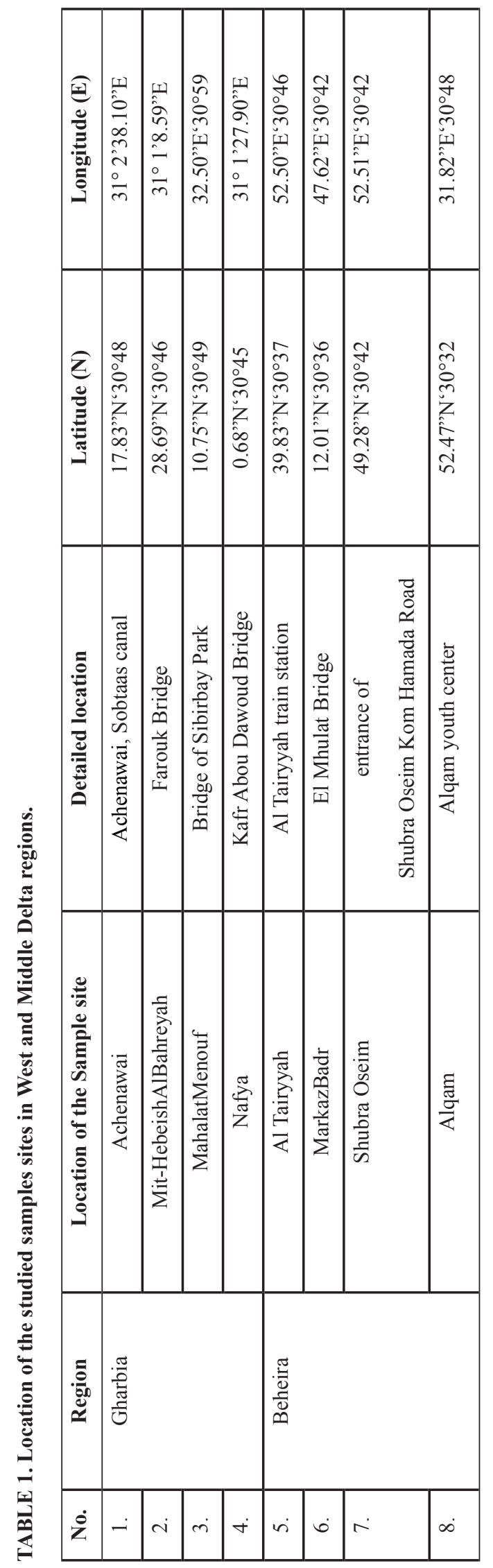



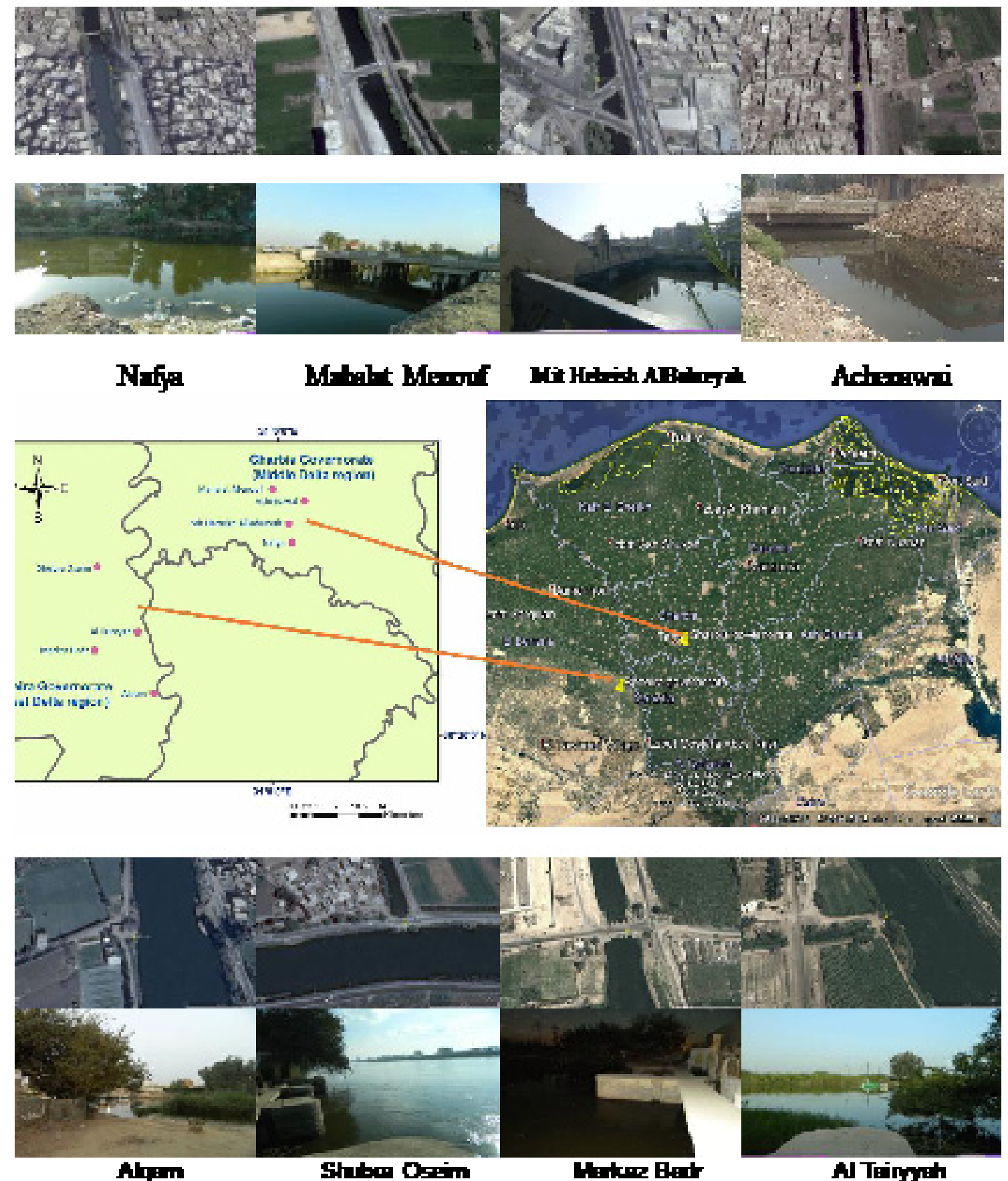

Fig. 1. Sampling sites in the middle delta and west delta regions (Gharbia and Beheira governorate). 


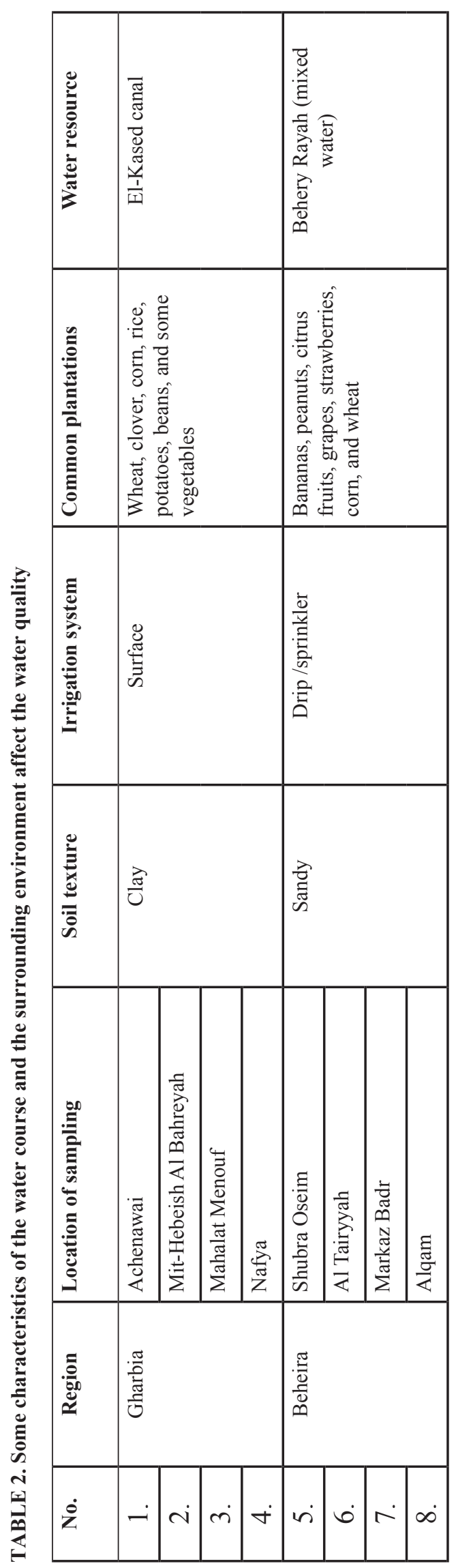

Env. Biodiv. Soil Security Vol. 3 (2019) agrochemicals.

\section{Water sampling and analyses}

Attempts were made to determine the physicochemical characteristics of the canal water various parameters such as electrical conductivity (EC), $\mathrm{pH}$, temperature, total solids (TS), total dissolved solids (TDS), total suspended solids (TSS), color, turbidity, chemical oxygen demand (COD) and $\mathrm{UV}_{254}$ absorbance of canal water sample as indicators of water quality (Table 3 ).

Water samples from the surface layer (10: 30 $\mathrm{cm}$ ) were collected in polyvinyl chloride bottles and the samples immediately were transferred to the laboratory in the tank icebox. Upon arrival at the laboratory, $\mathrm{pH}$ and the salinity (EC), turbidity, TSS, TDS, total solids (TS) and chemical oxygen demand (COD) were measured in non-filtered water samples (APHA, 1998). For color determination, $10 \mathrm{ml}$ of the sample was centrifuged at $3500 \mathrm{rpm}$ for $10 \mathrm{~min}$. The supernatant solution was collected to determine the water-color. Part of the samples was filtered immediately upon arrival in the laboratory to estimate the concentration of chloride ions. Water $\mathrm{pH}$ and electrical conductivity were measured using H1 2211 Hanna digital pH meter and AD8000 conductivity meter, respectively. The SM1200 UV Vis Spectrophotometer also was used in the measurement of various chemical parameters including color, $\mathrm{UV}_{245}$ absorbance, and turbidity parameters. All chemical used for chemical analysis were laboratory analytical grad, and distilled water was redistilled water obtained from the Central Laboratory Tanta University.

Aftercalibration and adjust the temperature. 250 $\mathrm{ml}$ of the water sample transferred into a preweighted evaporating dish in order to estimate the total solids (TS). The sample was evaporated to dryness. To estimate the total dissolved solids (TDS), the same steps were followed, but on a filtered water sample and calculated by the same equation. Total suspended solids (TSS) are calculated arithmetically according to the following equation: $\mathrm{TS}=\mathrm{TSS}+\mathrm{TDS}$. All measured parameters (TS, TSS, and TDS) were expressed as $\left(\mathrm{mg} \mathrm{L}^{-1}\right)$. Turbidity and color values of the samples were determined spectrophotometrically according to Goodner (2009) and Cuthbert and Giorgio (1992), at a wavelength of 750 and $440 \mathrm{~nm}$, respectively. The $\mathrm{Cl}^{-}$ion concentration in water samples was assessed by titration with Argentometric method (Paustian 1986). Potassium permanganate $\left(\mathrm{KMnO}_{4}\right)$ was used for 


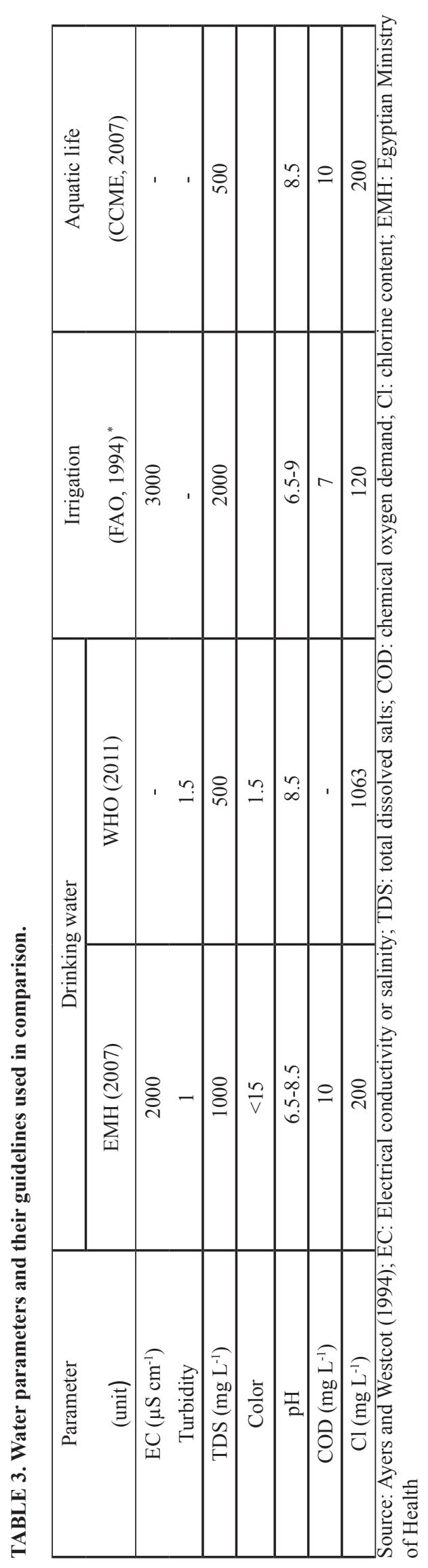

measuring the chemical oxygen demand (COD) spectrophotometrically according to Jiang and Zheng (2009).

\section{Statically analysis}

Microsoft Excel 2010 was used to calculate the range, mean and standard deviation for all sampling sites and sampling dates. SASS (ver. 9.2) was also used for statistical analysis of the results obtained using analysis of one-way ANOVA $(p<0.05)$. Detection of differences between the location and dates means for significance was done by Duncan's multiple range tests.

\section{Results}

In all studied parameters (except $\mathrm{pH}$ ) there were significant differences among the means of sample collection sites and dates, also, the interaction between studied variables. Electrical conductivity (EC) of water contains various ions in water solution such as sulfate, bicarbonate, chloride, magnesium, sodium, and calcium so it can be used as a measure of pollution in the watercourse (Das et al. 2006). EC values of the collected water samples recorded in Table 4 and illustrated in Fig. 2. Data showed that the EC values ranged from 395 to $703 \mu \mathrm{S} \mathrm{cm}{ }^{-1}$. These values are lower than those of Egyptian law and also from WHO limits (for drinking water) as well as being less than the limits of valid irrigation water identified by the FAO and also the limits of damage to aquatic life identified by the Canadian Environmental Quality Guidelines (CCME). January and August had the highest value of EC (588.42, $580.08 \mu \mathrm{S} \mathrm{cm}^{-1}$, respectively), On the other hand, may record the lowest value of EC throughout the year $\left(459.75 \mu \mathrm{S} \mathrm{cm}^{-1}\right)$. Achenawai site recorded the highest $\mathrm{EC}$ value of $578.94 \mu \mathrm{S}$ $\mathrm{cm}^{-1}$, while Alqamsite recorded the lowest values at all locations $\left(522.92 \mu \mathrm{S} \mathrm{cm} \mathrm{cm}^{-1}\right)$. The annual average of the EC values of Beheira and Gharbia governorates were very convergent, which recorded 542.06 and $544.22 \mu \mathrm{S} \mathrm{cm}^{-1}$, respectively. Sampling sites in Gharbia are characterized by high variation in the recorded values according to the location or date of the sampling, while the sampling sites of Beheira are characterized by some homogeneity according to the location of the sample collection.

Turbidity is a physical characteristic of water, which expresses the optical properties that cause dispersion or absorption of light by the suspended particles in water, in the sense that it is a measure of the amount of fine suspended matter in water 
(Wagner et al. 2006). The importance of turbidity is that it may alter the ecosystem in the watercourse by shading the aquatic plants and other fauna (DRI 2010). It also protects microorganisms, which may pose a health hazard (Nkansah et al. 2011). In general, the turbidity estimate reflects the amount of water pollution (Siliem 1995). Results showed turbidity values of the collected water samples in Table 4 and Fig. 3. All values were outside the maximum permissible limit for drinking water according to Egyptian Law and WHO limits, as well as had a wide variation in their values. The recorded values ranged from 6.06 to 47.43 NTU. The highest values recorded in August (40.79 NTU) while the lowest one recorded in January (13.7 NTU). Nafya recorded the highest value of turbidity (25.92 NTU) while Mit-Hebeish Al Bahreyah, Mahalat Menouf, and Markaz Badr recorded the lowest values $(21.44,21.52$ and 22.42 NTU, respectively). The annual average of Gharbiais higher than the annual average value of Beheira (23.57, 22.84 NTU, respectively). The values recorded in both governorates were also very variable.

Turbidity in natural waters is caused by the presence of suspended matter which usually consists of a mixture of inorganic matter, such as clay and soil particles, and organic matter (OwusuBoateng and Kumi-Aboagye 2013). The velocity of water current and wind movement affect the distribution of sediments in a watercourse, which affects the turbidity in water (Wetzel and Likens 1991) and this is for the inorganic matter. While, leak nitrogen and phosphate nutrients from irrigated fields enhance photosynthesis, phytoplankton production and elevate TSS and turbidity values (Rahman et al. 2008). This explains, the elevated of TSS and turbidity values in September (after a flooding month) and other hot months, while its decline in January (drought period) and winter months. In the summer months, the water flow rate increases, the nutrient leaches, and the temperature increase, which increase the growth of phytoplankton (organic matter) and suspended particles (inorganic).

Color is an optical attribute of material, due to the emission, transfer or reflection of light. The water sample color is estimated on a filtered sample. Due to the ability of most people to detect the color highest of $15 \mathrm{mg} \mathrm{Pt} \mathrm{L}^{-1}$, this value has been set as a limit allowed for the water sample color. From the obtained data (Table 4 and Fig. 4), there was a significant divergence between color values in the different water samples, values ranged from 4.52 to $122.63 \mathrm{mg} \mathrm{L}^{-1}$. The maximum monthly color values were recorded in July $\left(101.52 \mathrm{mgL}^{-1}\right)$ while the lowest values were recorded in November and December (23.86 and $22.68 \mathrm{mgL}^{-1}$, respectively). The highest value of color recorded in Achenawai site $\left(69.58 \mathrm{mgL}^{-}\right.$ ${ }^{1}$ ), while the lowest color values recorded in Mahalat Menouf and Al Tairyyah (38.38 and 39.56 $\mathrm{mgL}^{-1}$, respectively), with no significant difference between them. The annual averages of the two governorates were very close (52.01 and $51.15 \mathrm{mg}$ $\mathrm{L}^{-1}$ for Gharbia and Beheira, respectively). There were variations among the average color values of Gharbia compared to the averages of Beheira.

TDS is a water characteristic that determines the concentration of dissolved inorganic and organic solids in water. It is closely correlated with the amount of water hardness and the buffering capacity of water. TDS can be considered as the sum of all positive and negative ions in water. TDS is measured because excessive amounts $(>500$ $\mathrm{mgL}^{-1}$ ) may be become unacceptable for drinking and many industrial uses and the increase of TDS value produce displeasing color, tastes, and odors and lead to exert osmotic pressure, which affects the aquatic life and may become carcinogenic, especially halogenated compounds (DRI 2010; El Shakour and Mostafa 2012). While, TS is the sum of TDS and TSS values, which expresses all dissolved or suspended solids in the water sample.

TDS values showed that the values of TDS were within the permissible limits according to different standards (Table 4 and Fig. 5). TDS values ranged between 236.67 and $457.67 \mathrm{mg} \mathrm{L}^{-1}$., The April and July months recorded the maximum values of TDS (304.67, $326.33 \mathrm{mg} \mathrm{L}^{-1}$ ) while March month recorded the lowest one $(299.33 \mathrm{mg}$ $\left.\mathrm{L}^{-1}\right)$. Achenawai site recorded the highest value of TDS (383.53 $\mathrm{mg} \mathrm{L}^{-1}$ ) while Alqam site was the least ever at $307.33 \mathrm{mg} \mathrm{L}^{-1}$. The annually average of Beheirawas lower than the annual average of Gharbia $\left(315,339 \mathrm{mg} \mathrm{L}^{-1}\right.$, respectively). The values recorded in Gharbia were more divergent than those recorded in Beheira, which showed homogeneity and convergence in the recorded values. In most of the months, the values recorded in Gharbia were higher than the values recorded in Beheira.

TSS values (Table 4 and Fig. 6) showed that the TSS values ranged from 0.33 to $100.67 \mathrm{mg}$ $\mathrm{L}^{-1}$, with a significant variation between locations 
and sampling dates. August month had the highest values of TSS $\left(59.5 \mathrm{mg} \mathrm{L}^{-1}\right)$ while January month had the lowest one $\left(13.25 \mathrm{mg} \mathrm{L}^{-1}\right)$. Achenawai site recorded the highest value of TSS $\left(60.56 \mathrm{mg} \mathrm{L}^{-1}\right)$ while Nafya and Mit-Hebeish Al Bahreyah sites recorded the lowest values (24.22 and $28.66 \mathrm{mg} \mathrm{L}^{-1}$, respectively). The annually average of Beheirais higher than the annual average of Gharbia (42.24, $34.12 \mathrm{mg} \mathrm{L}^{-1}$, respectively). The values recorded in both governorates were also very variable. In most months, the values recorded in Beheira were higher than the values recorded in Gharbia gov. for most months of the year ( 8 months). There are no permissible limits for TS value in the guidelines adopted in this study. TS values (Table 4 and Fig. 7) demonstrate that TS recorded the highest values in April and July months (304.67, 326.33 $\mathrm{mg} \mathrm{L}^{-1}$ ) while recording the lowest one in March (299.33 $\left.\mathrm{mg} \mathrm{L}^{-1}\right)$. Achenawai site recorded the highest value of TS (444.08 $\left.\mathrm{mg} \mathrm{L}^{-1}\right)$ while Nafya and Alqam sites had the lowest values (346.42 and $343.58 \mathrm{mg} \mathrm{L}^{-1}$, respectively). The annual average of Beheira was below the annual average values of Gharbia (357.85, $373.17 \mathrm{mg} \mathrm{L}^{-1}$, respectively). The monthly values recorded in Gharbiawere higher and more convergence compared with values recorded in Beheira, in most months of the year (7 months).

The $\mathrm{pH}$ measurements are one of the most wide spread analyses in water testing. It is indicative of acidity of the sample, infact, indicates the activity of the hydrogen ion. Its value ranges from $0-14$ and sample with $\mathrm{pH} 7.0$ is considered neutral, while with a $\mathrm{pH}$ above 7.0 are considered bases; those between 0 and 7 are rate as acids. The ideal range for most organisms is between 6.5-8.2 (Campbell and Wildberger 1992). It is the principal limiting factor with temperature, affecting the solubility and availability of major nutrients or minor elements. A decrease in $\mathrm{pH}$ values could also decrease the solubility some elements like Molybdenum, while low $\mathrm{pH}$ increases the solubility of other elements such as $\mathrm{Al}, \mathrm{Fe}, \mathrm{Mn}, \mathrm{Cu}, \mathrm{Cd}, \mathrm{Hg}$, and B (DWAF 1996).

Potential of hydrogen $(\mathrm{pH})$ values (Table 4 and Fig. 8) show that there were significant differences among the means of some studied factors (sampling site and the interaction between sampling site and the sample timing), while there were no significant differences among the means of samples timing. The $\mathrm{pH}$ values did not exceed the stipulated limits in the guidelines adopted in this study. all values were in the alkaline range.
There is no value in the acid range. There is a significant convergence of $\mathrm{pH}$ values, which range from 7.02 to 8.03 . The maximum $\mathrm{pH}$ value recorded in December (7.8), while June was the lowest one (7.25) . The sampling site "Achenawai" recorded the highest $\mathrm{pH}$ value (7.6). The sampling sites Mahalat Menouf, MitHebeish Al Bahreyah, and Alqam did not differ significantly and recorded the lowest $\mathrm{pH}$ values (7.44, 7.45 and 7.46, respectively). The annual average of the two governorates was very close (with 7.5 and 7.47, for Gharbia and Beheira, respectively). The values of Gharbia sites were dissimilar in comparison to those of Beheira.

Chloride $\left(\mathrm{Cl}^{-}\right)$is the major anion exists in the natural water. Most plants are very sensitive to chloride ions. Chloride concentration is very vital for water suitability for irrigation purposes. high concentration of chloride ion in irrigation water case plant toxicity (Ayers 1975). High chloride concentration in water correlated with contamination with organic wastes (Thresh et al., 1949). The value of chloride ion concentration showed that chloride ions concentrations were within the permissible limits of guidelines adopted in this study (Table 4 and Fig. 9). There was a significant distinction between chloride ion concentrations in the different water samples, values ranged from 29.07: $68.2 \mathrm{mg} \mathrm{L}^{-1}$. Maximum values recorded in December $\left(57.45 \mathrm{mg} \mathrm{L}^{-1}\right)$ while the lowest values recorded in May (37.65 $\mathrm{mg} / \mathrm{L}$ ). The Mit-Hebeish Al Bahreyah recorded the highest value of chloride ion concentration (51.63 $\mathrm{mg} \mathrm{L}^{-1}$ ), while Alqam recorded the lowest value of chloride ion concentration $\left(43.55 \mathrm{mg} \mathrm{L}^{-1}\right)$. There was a convergence between the average annual of the two governorates (with 49.1 and 46.6, for Gharbia and Beheira, respectively). The monthly average values of ion conc. in Beheira sites were more varied than those in Gharbia.

The use of ultraviolet (UV) measurement as evidence of the removal of organic pollutants from water was suggested by Bahr et al. (2007). Yang et al. (2008) also used $\mathrm{pH}$ and UV absorption to monitor inorganic pollutants in the Lemming River Basin in Daqing, China. As nearly all organic matter shows characteristic UV absorbance in the range of 215: $316 \mathrm{~nm}$ (particularly in $254 \mathrm{~nm}$ ). The values of the $\mathrm{UV}_{254}$ absorption (Table 4 and Fig. 10) show that there was a variance in the measurements, where it is ranged from 0.01 to 0.14 . The highest value recorded in July (0.092), while the lowest values recorded in December, 


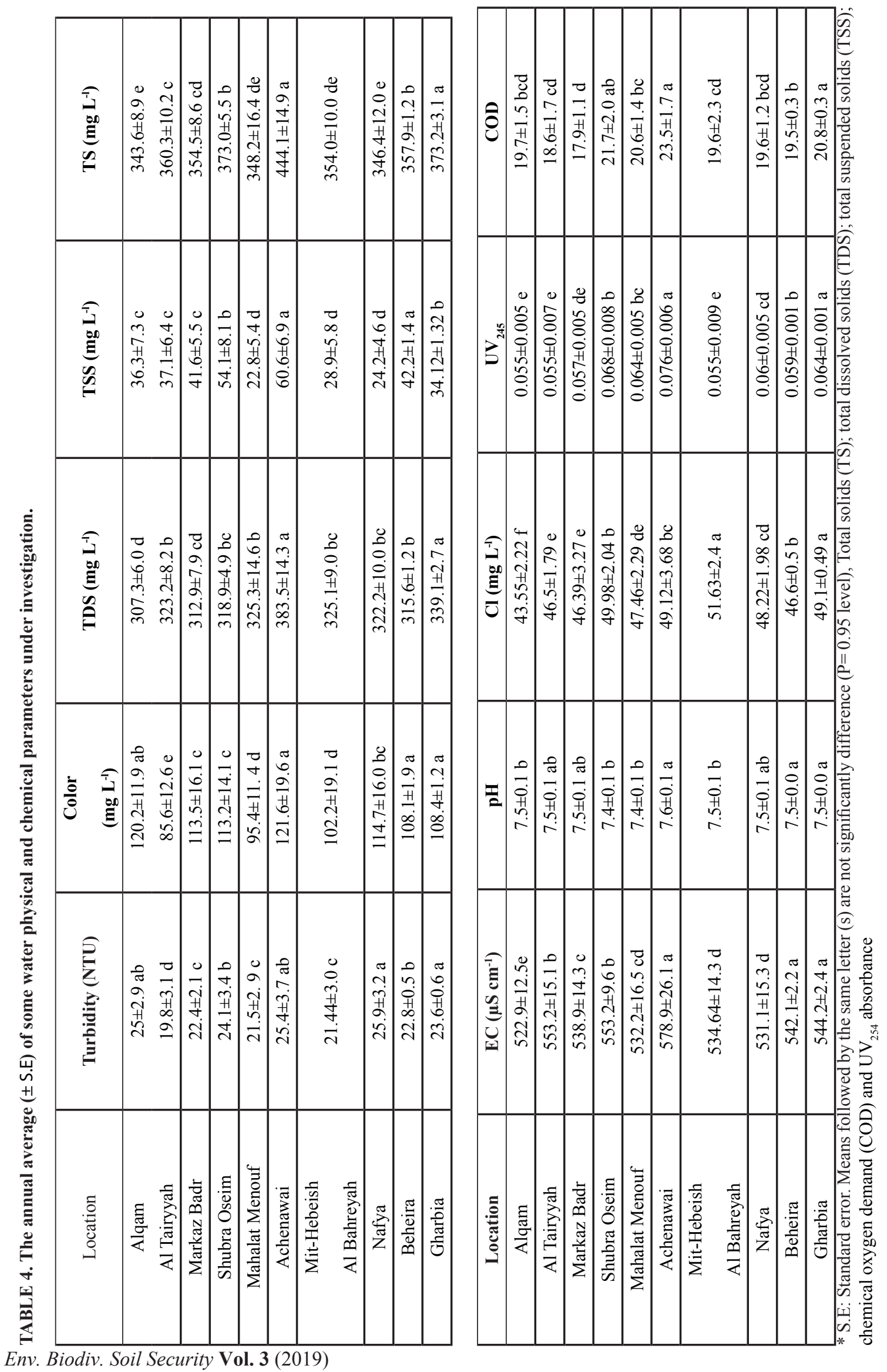


A
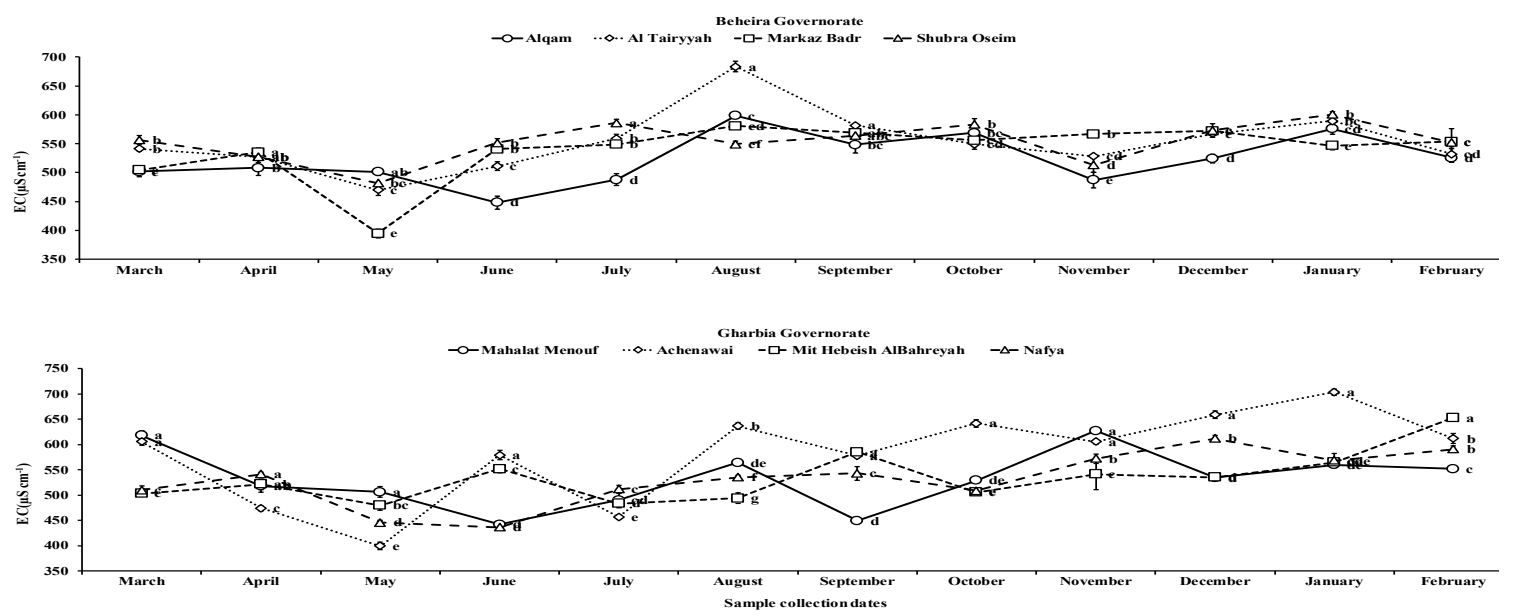

B

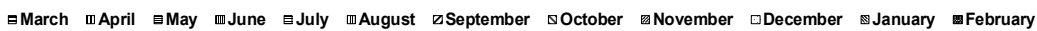

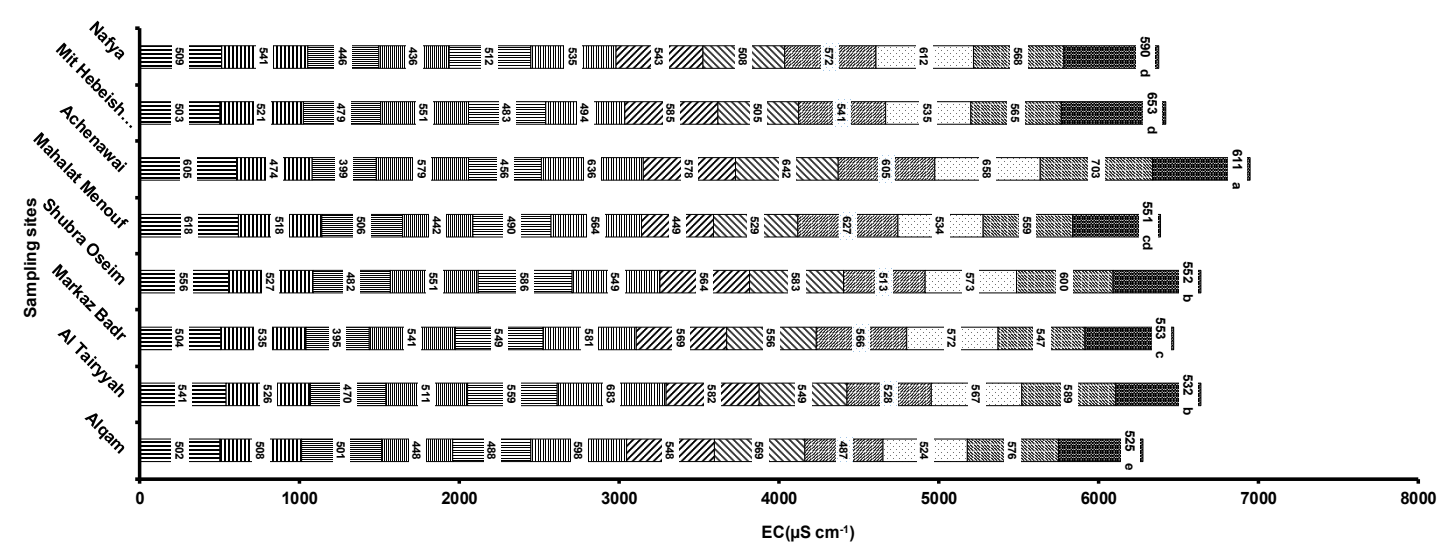

C

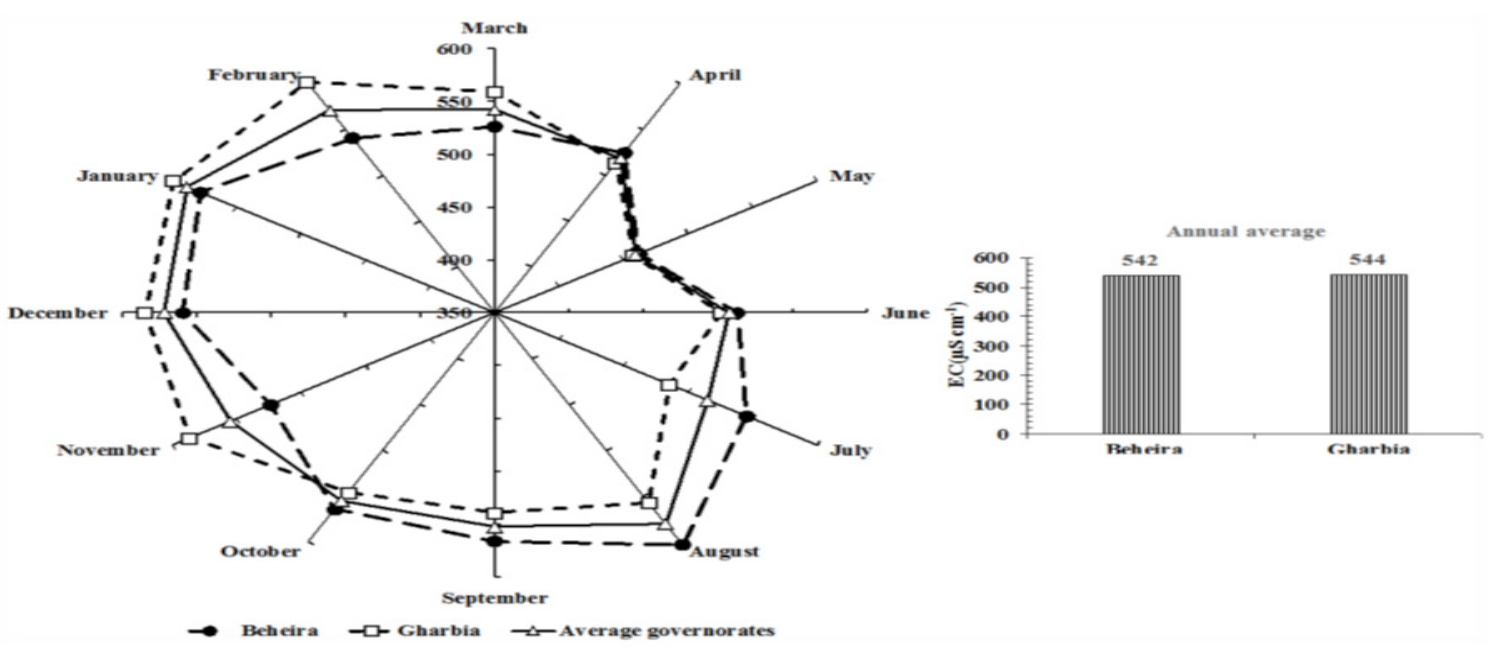

Fig. 2. EC values $\left(\mu \mathrm{S} \mathrm{cm}^{-1}\right)$ at investigated sites in the west and middle delta regions (A: Site monthly average; B: site average and the cumulative value of water parameter and $C$ : region monthly averages and the annual averages). 
A
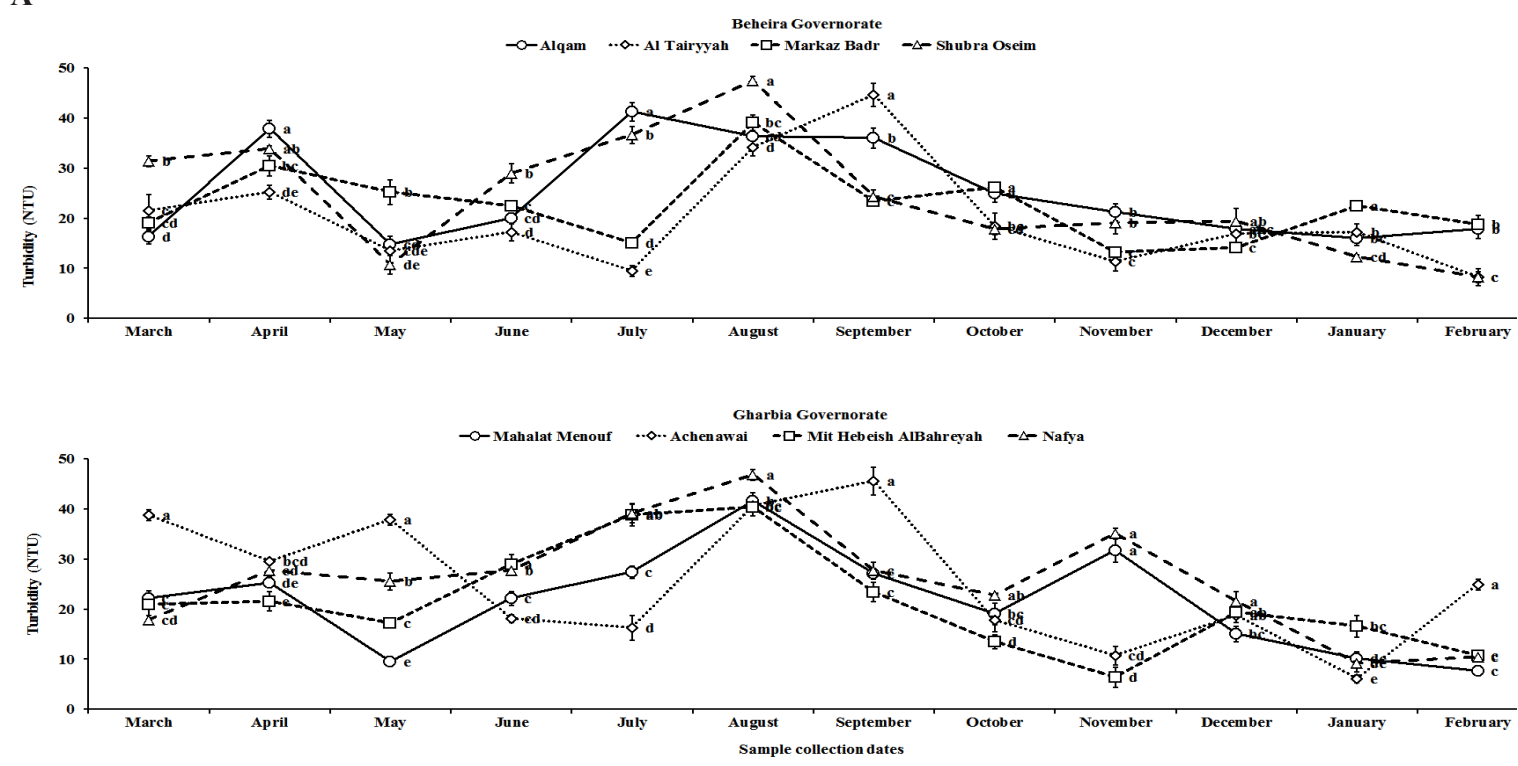

B

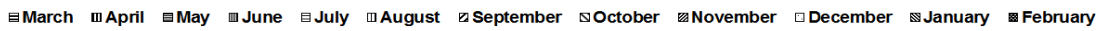

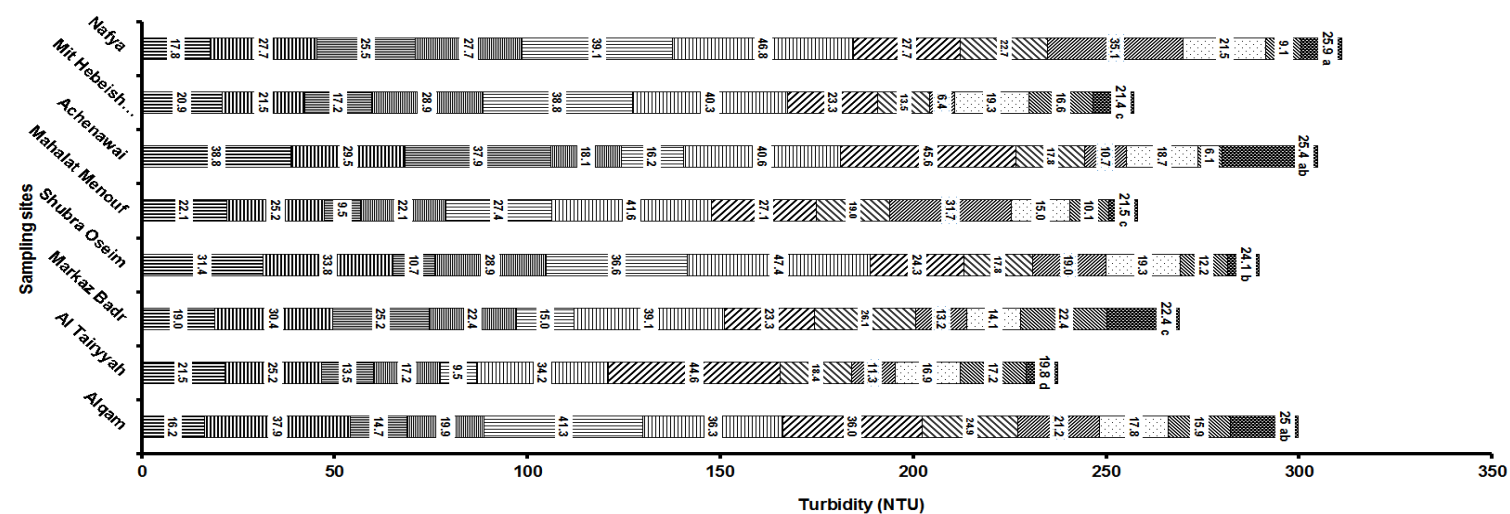

C
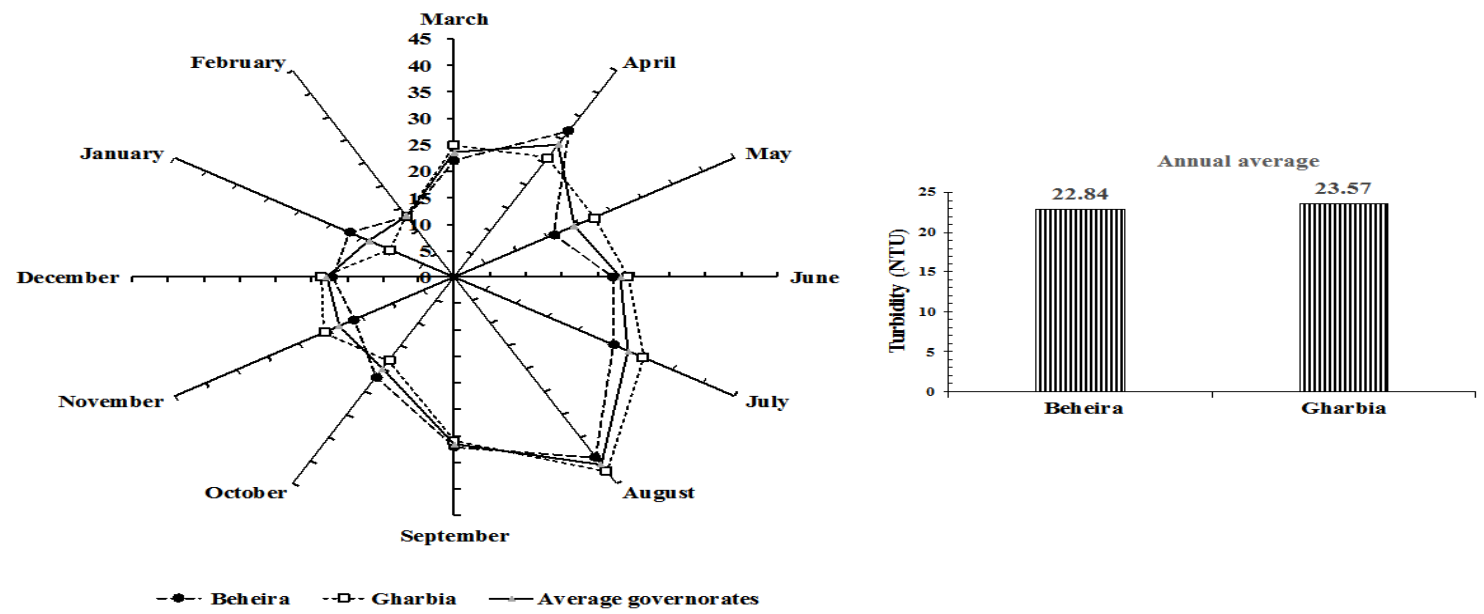

Fig. 3. Turbidity values (NTU) at investigated sites in the west and middle delta regions (A: Site monthly average; $B$ : site average and the cumulative value of water parameter and $C$ : region monthly averages and the annual averages).

Env. Biodiv. Soil Security Vol. 3 (2019) 
A
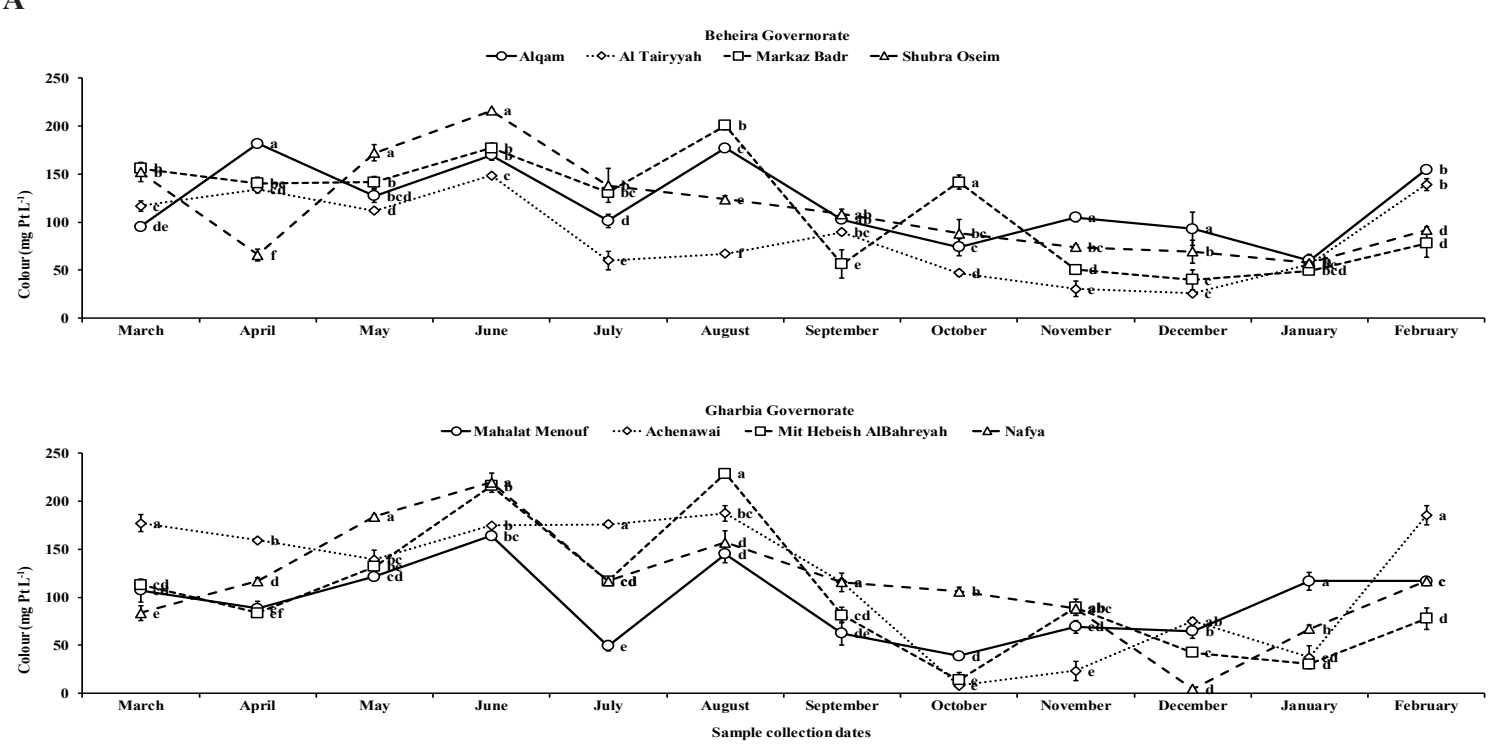

B

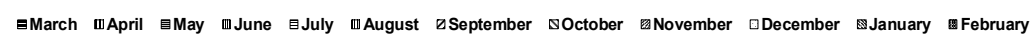

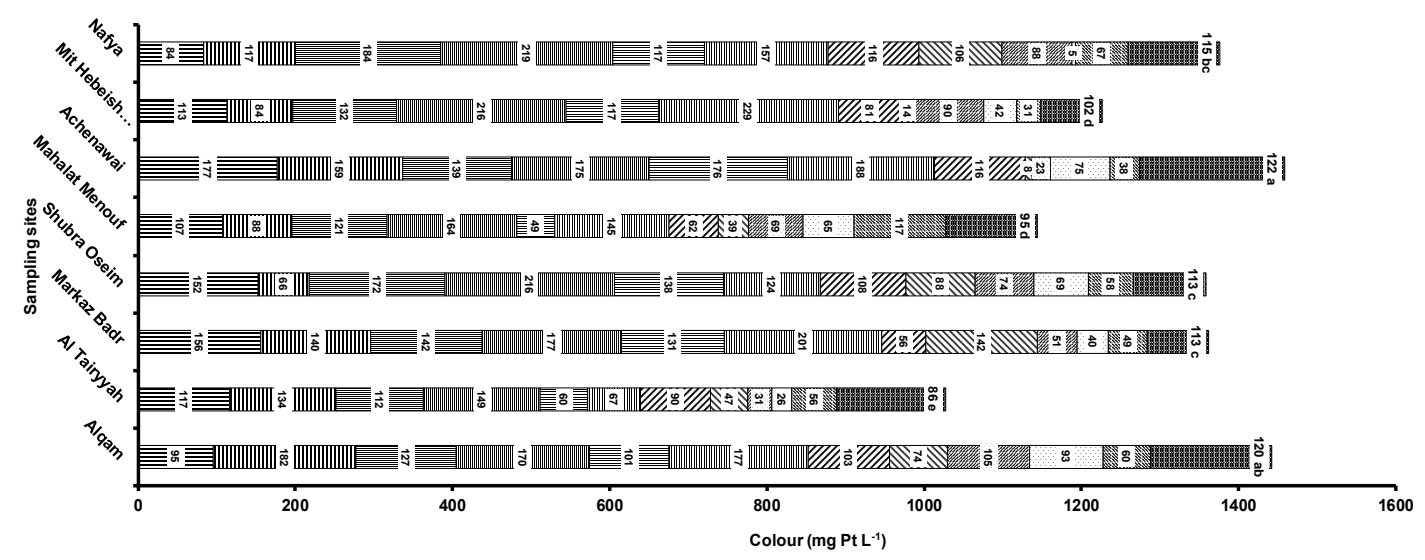

C
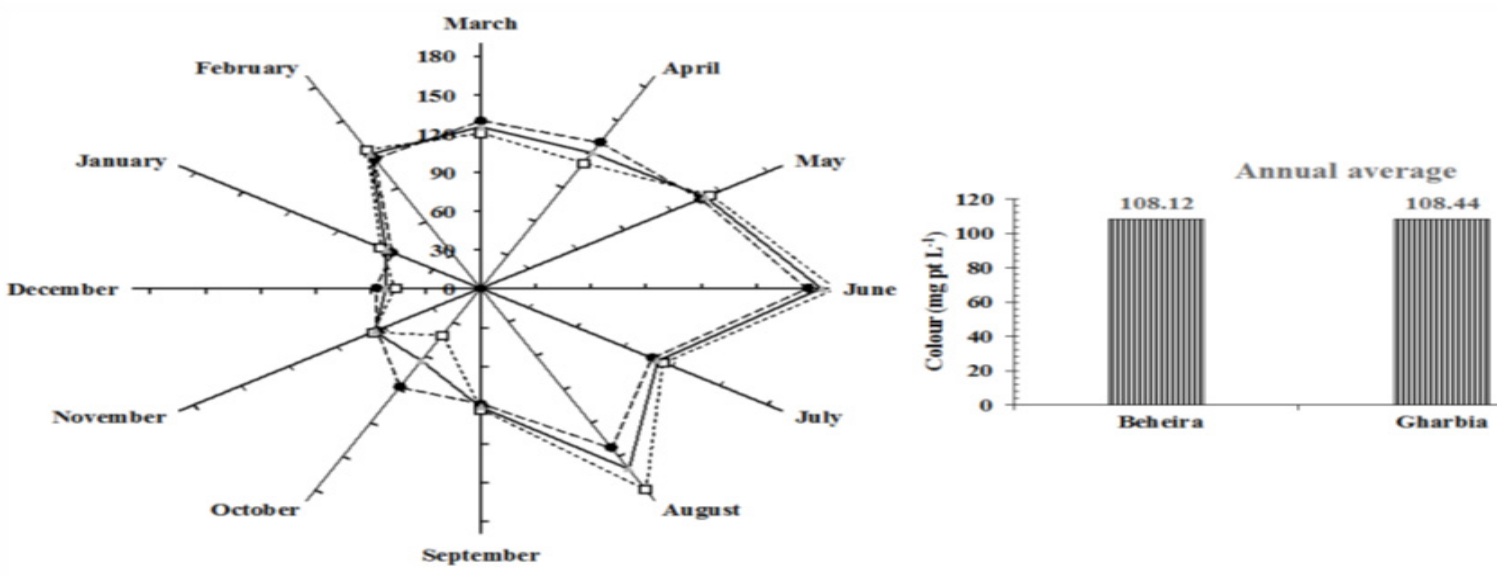

Fig. 4. Color (mg Pt $\left.\mathrm{L}^{-1}\right)$ at investigated sites in the west and middle delta regions (A: Site monthly average; B: site average and the cumulative value of water parameter and $C$ : region monthly averages and the annual averages). 
A

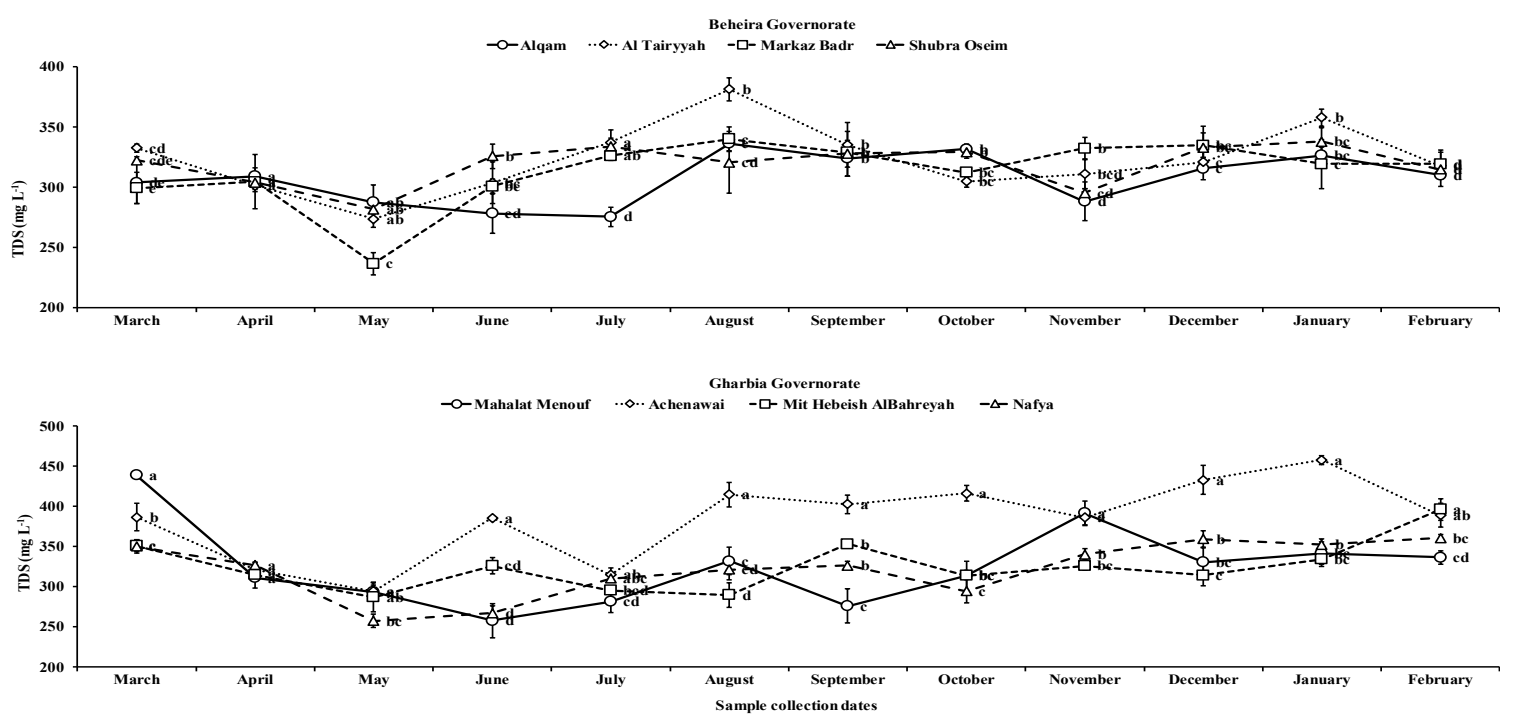

B

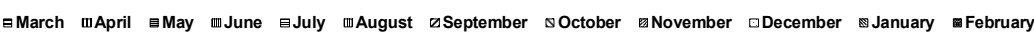

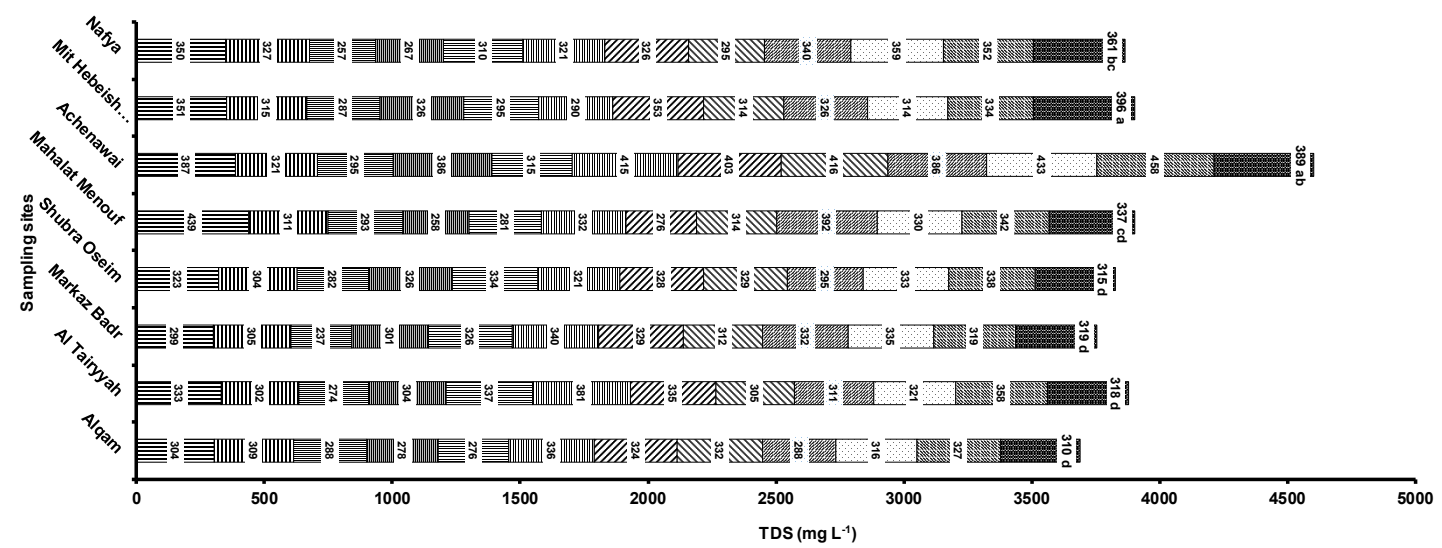

C
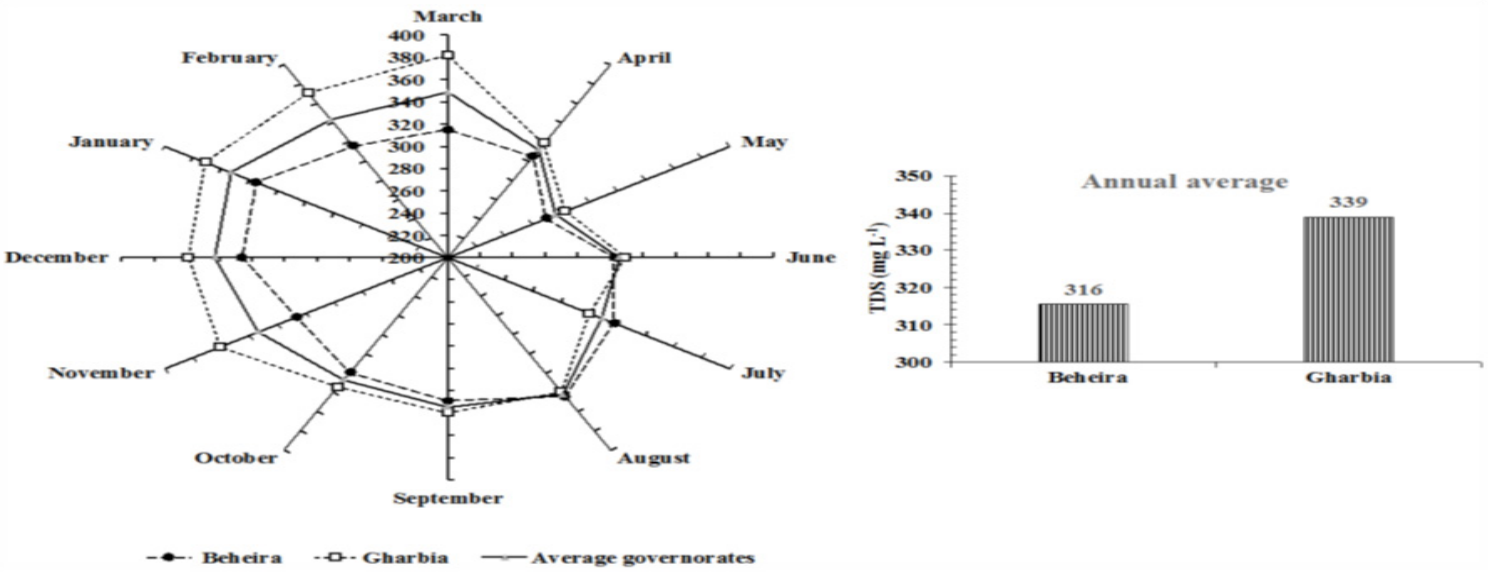

Fig. 5. TDS values $\left(\mathrm{mg} \mathrm{L}^{-1}\right)$ at investigated sites in the west and middle delta regions (A: Site monthly average; B: site average and the cumulative value of water parameter and $C$ : region monthly averages and the annual averages).

Env. Biodiv. Soil Security Vol. 3 (2019) 
A
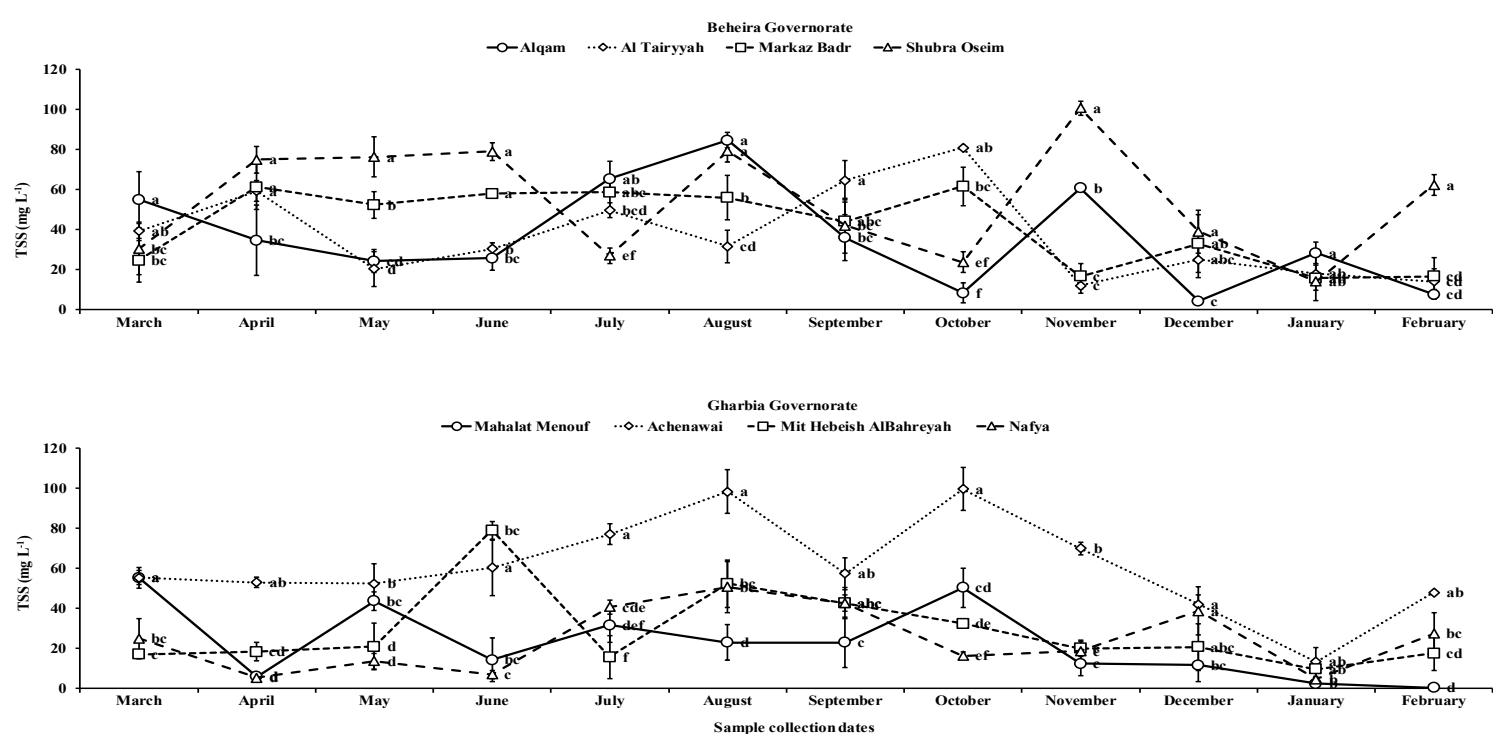

B

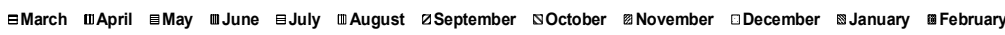

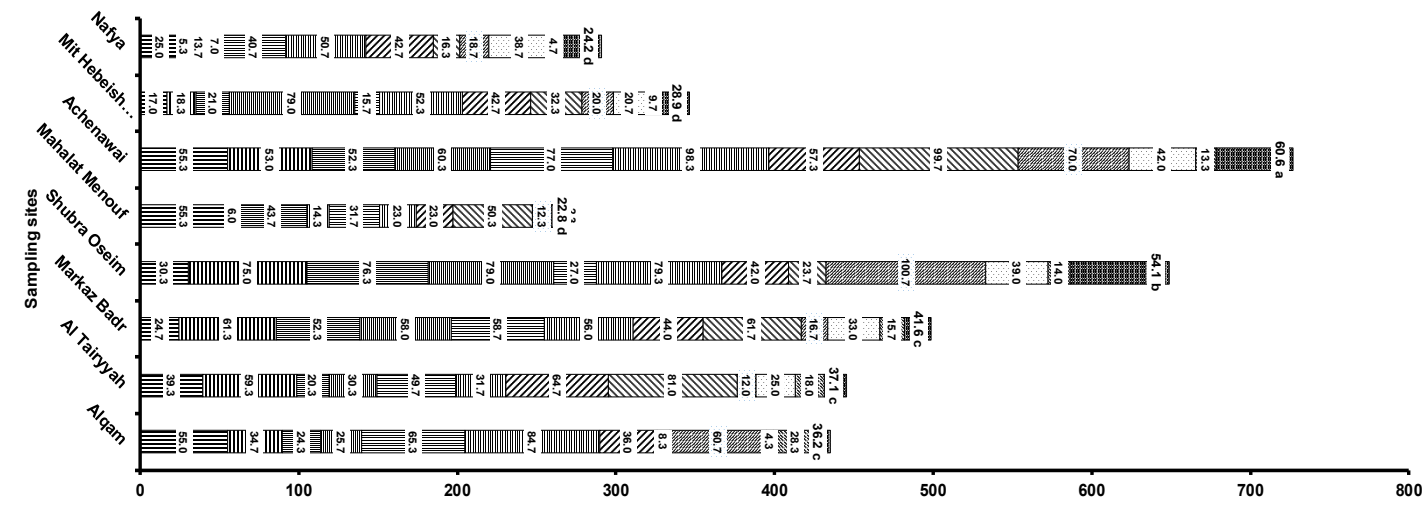

C
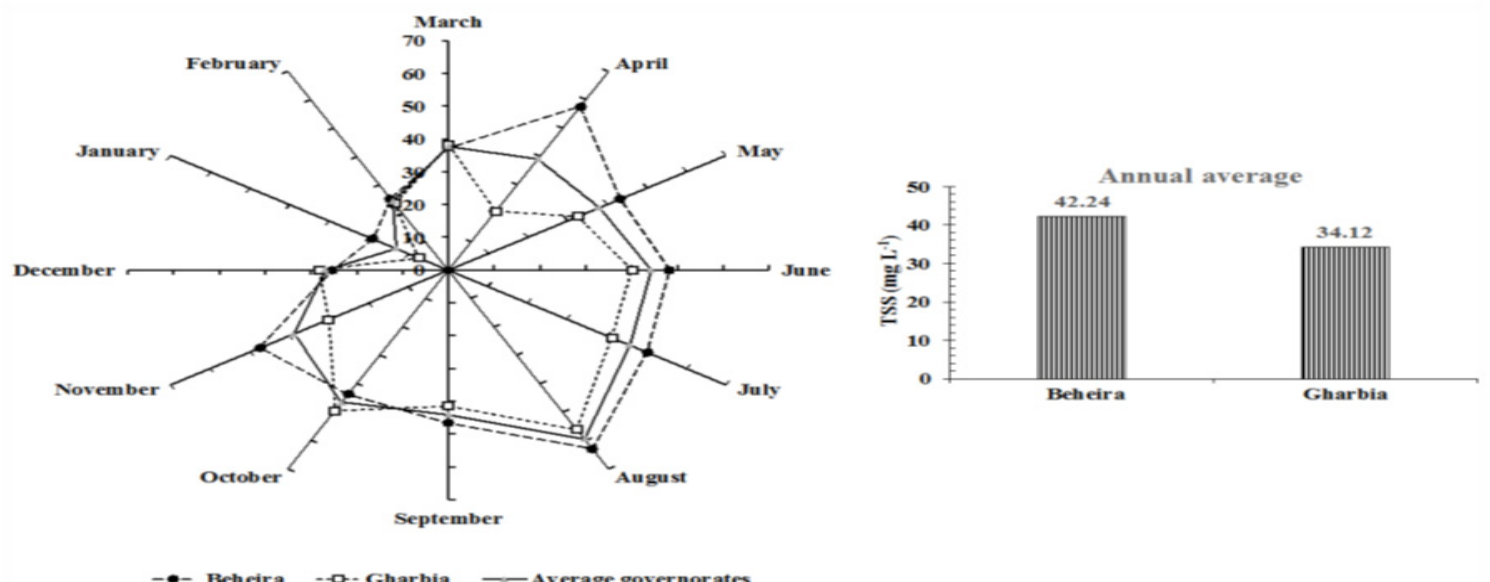

Fig. 6. TSS values $\left(\mathrm{mg} \mathrm{L}^{-1}\right)$ at investigated sites in the west and middle delta regions (A: Site monthly average; B: site average and the cumulative value of water parameter and $C$ : region monthly averages and the annual averages). 
A
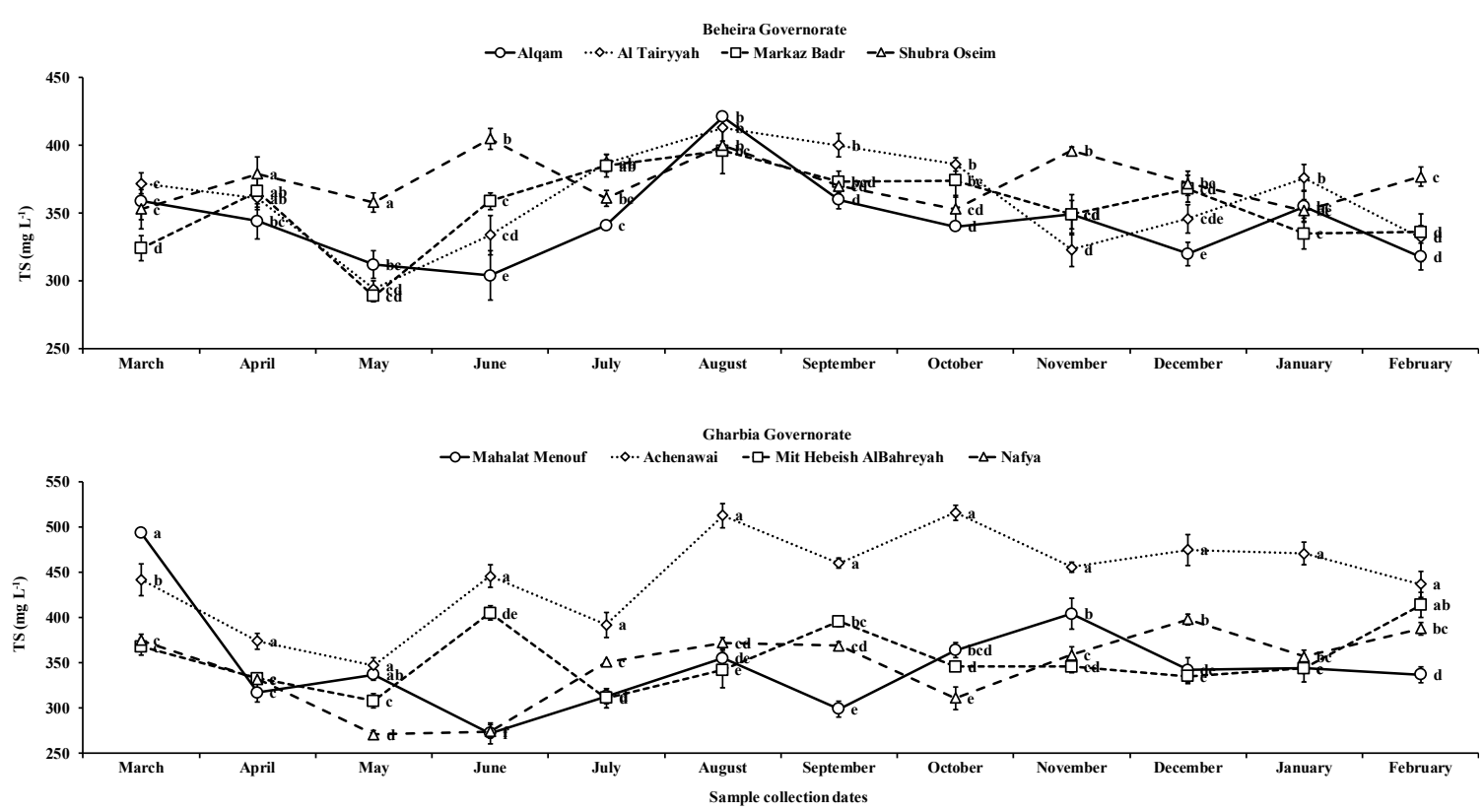

B

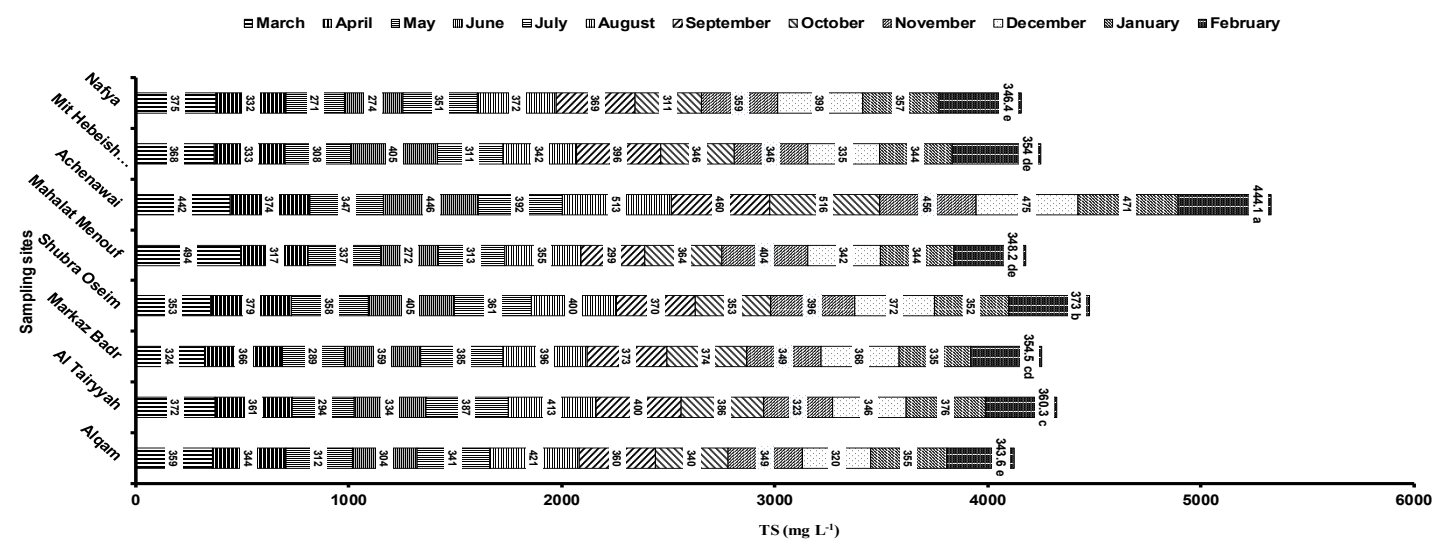

C
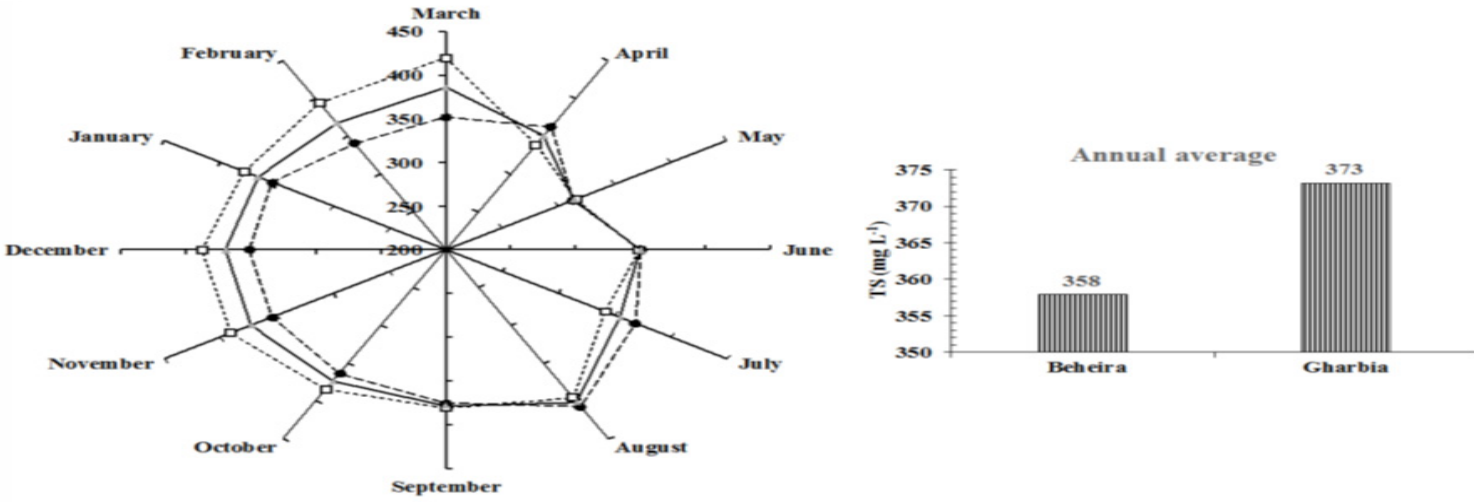

Fig. 7. TS values $\left(\mathrm{mg} \mathrm{L}^{-1}\right)$ at investigated sites in the west and middle delta regions (A: Site monthly average; B: site average and the cumulative value of water parameter and $C$ : region monthly averages and the annual averages).

Env. Biodiv. Soil Security Vol. 3 (2019) 
A
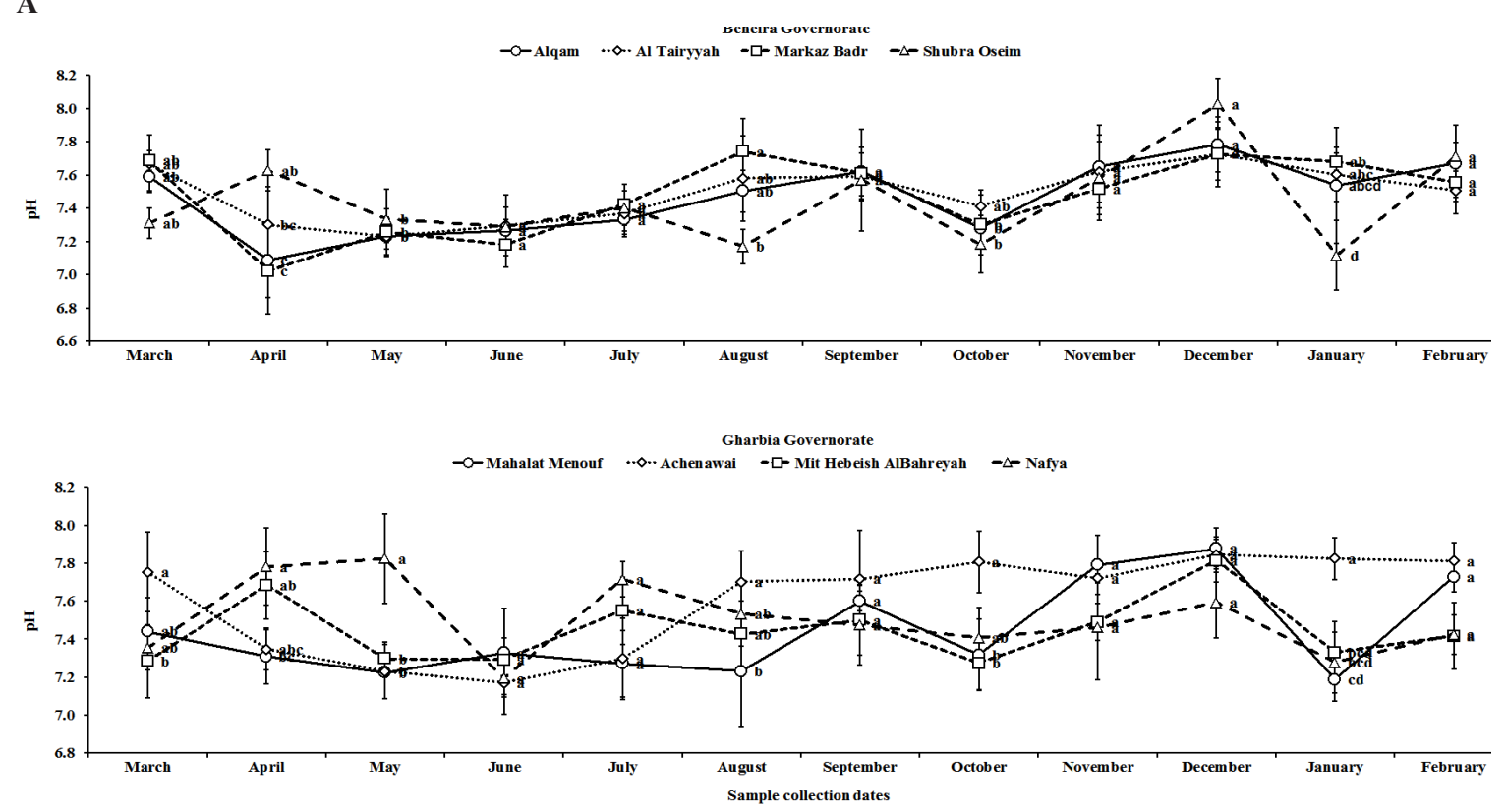

B

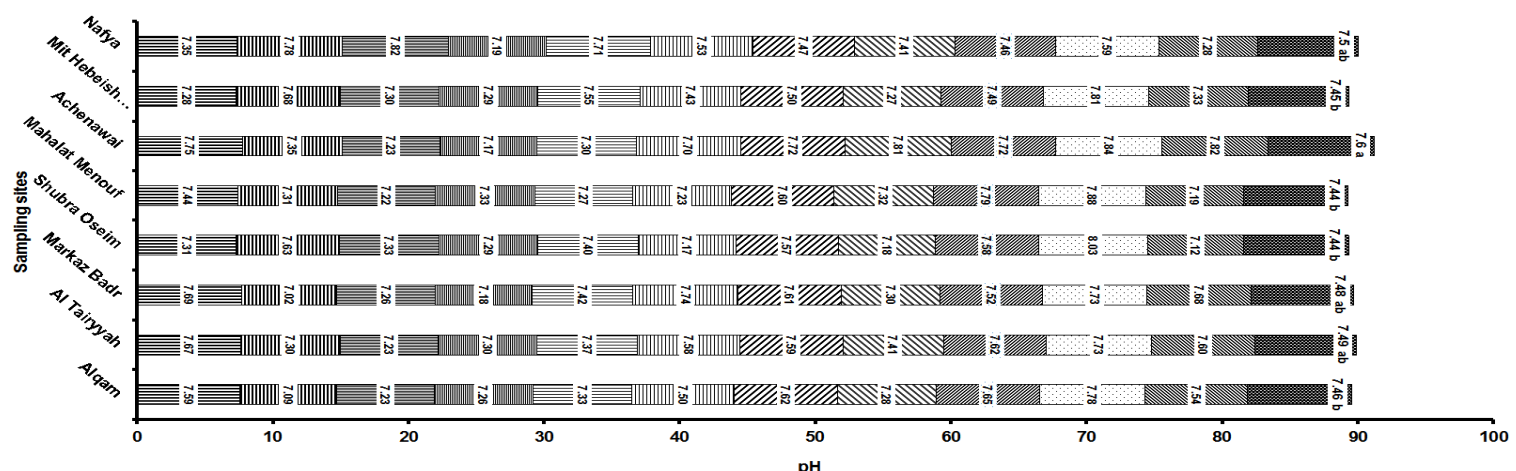

C

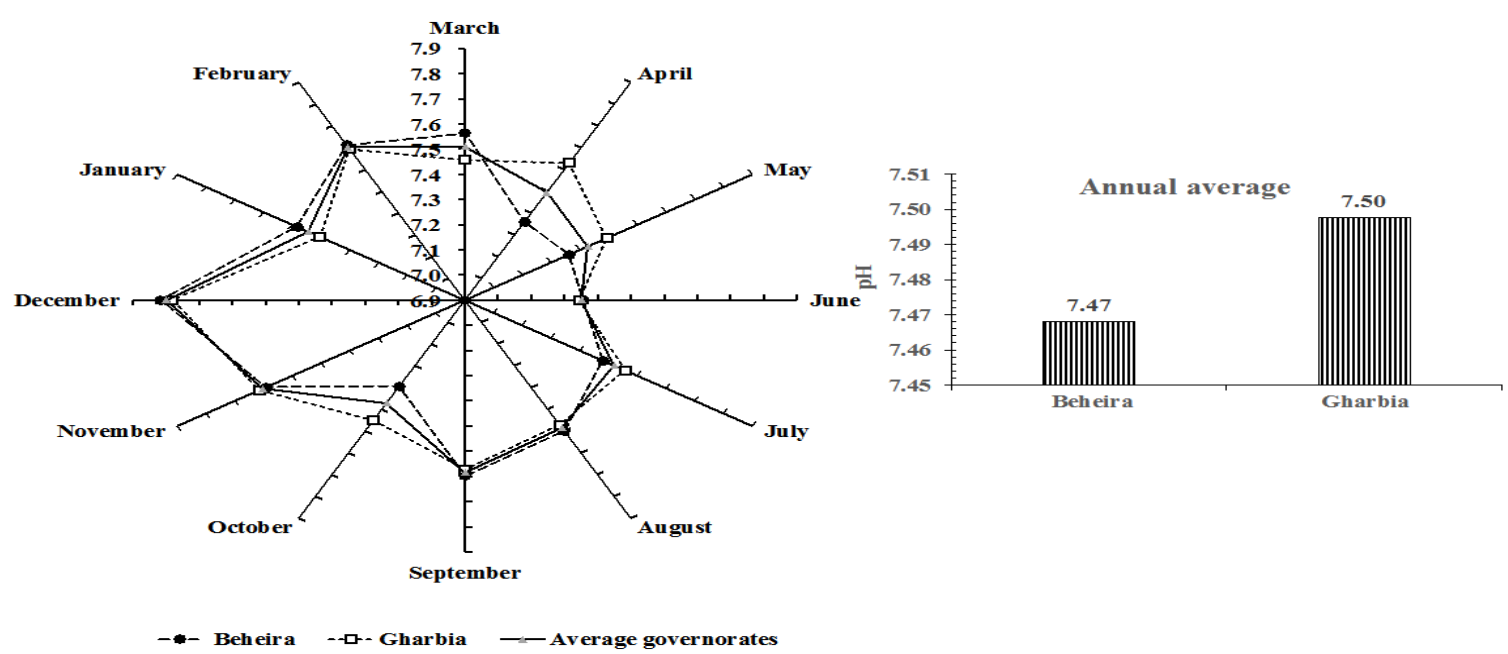

Fig. 8. $\mathrm{pH}$ values at investigated sites in the west and middle delta regions (A: Site monthly average; B: site average and the cumulative value of water parameter and $C$ : region monthly averages and the annual averages). 
A
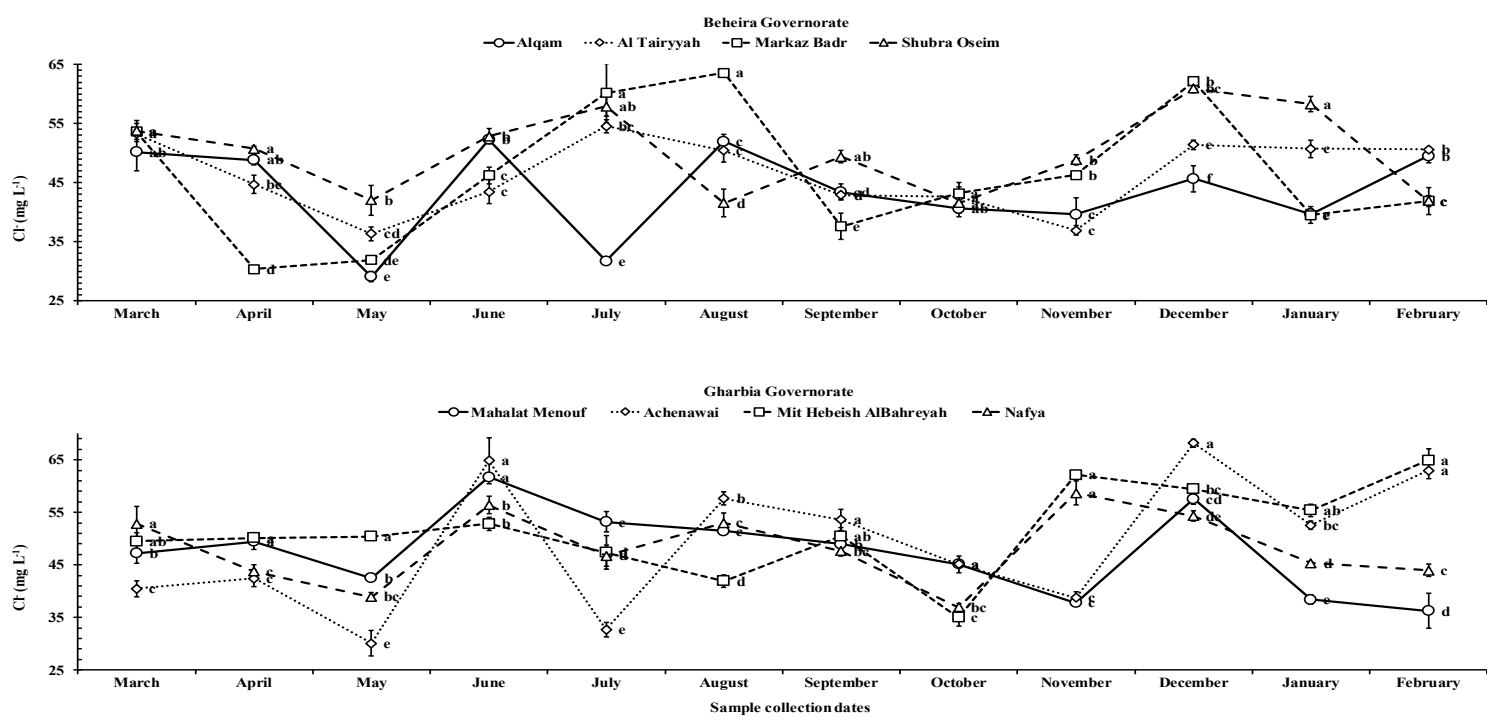

B

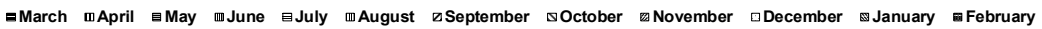

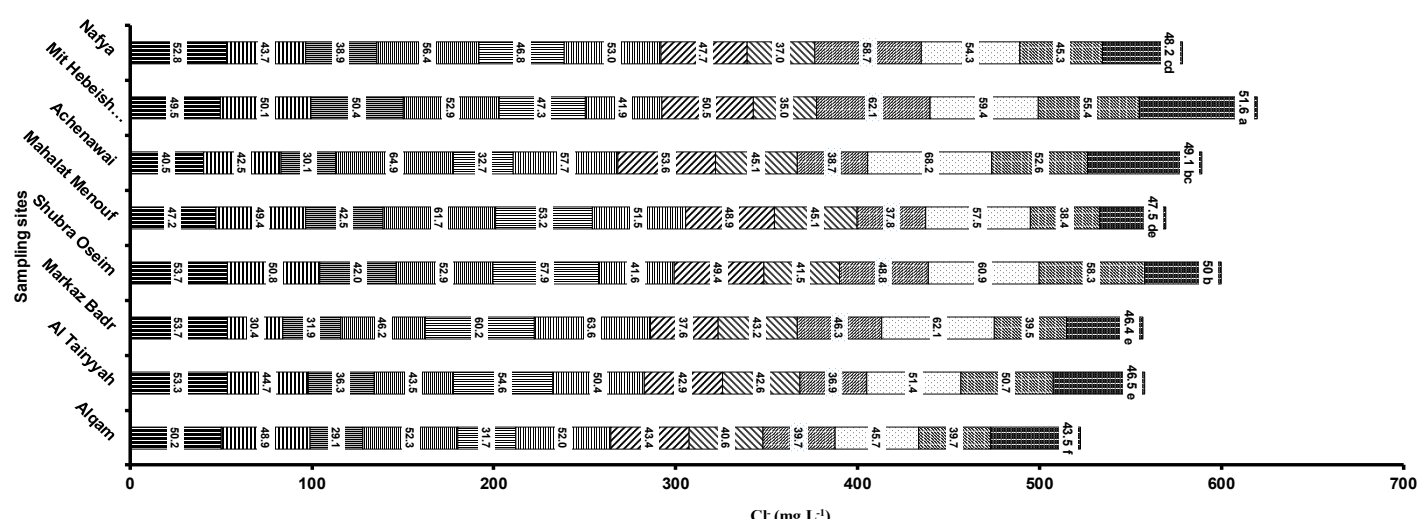

C
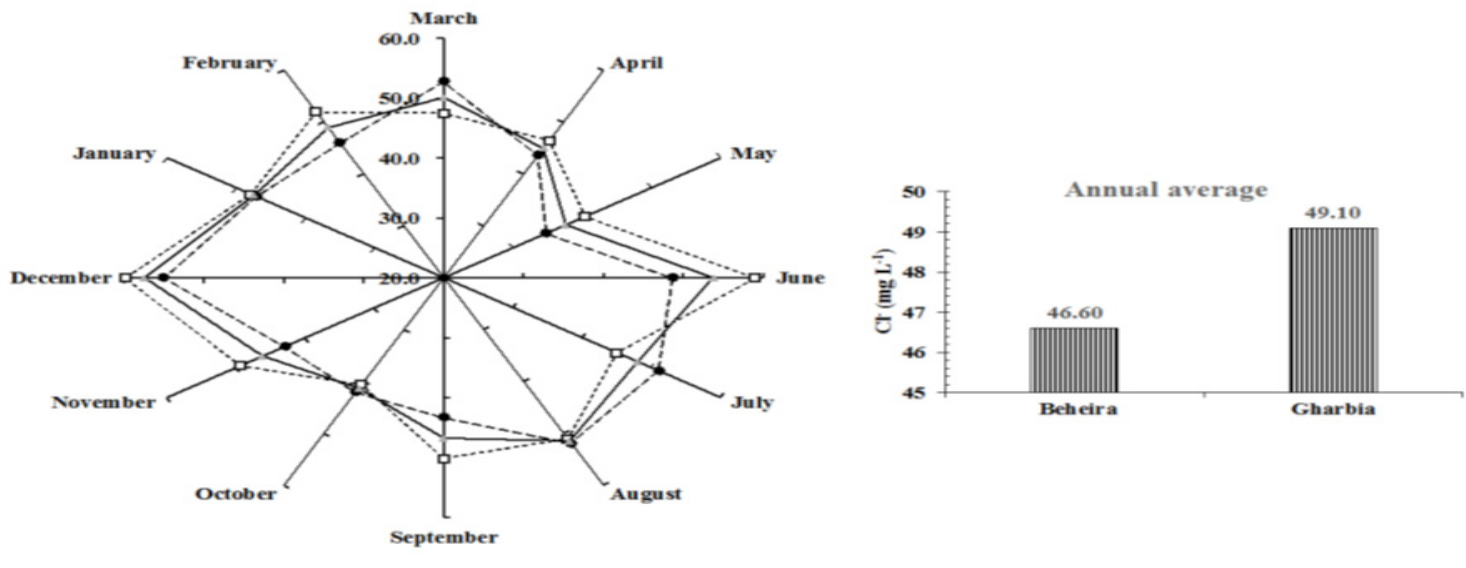

Fig. 9. $\mathrm{Cl}^{-}$ion content $\left(\mathrm{mg} \mathrm{L}^{-1}\right)$ at investigated sites in the west and middle delta regions (A: Site monthly average; B: site average and the cumulative value of water parameter and $C$ : region monthly averages and the annual averages).

Env. Biodiv. Soil Security Vol. 3 (2019) 
A
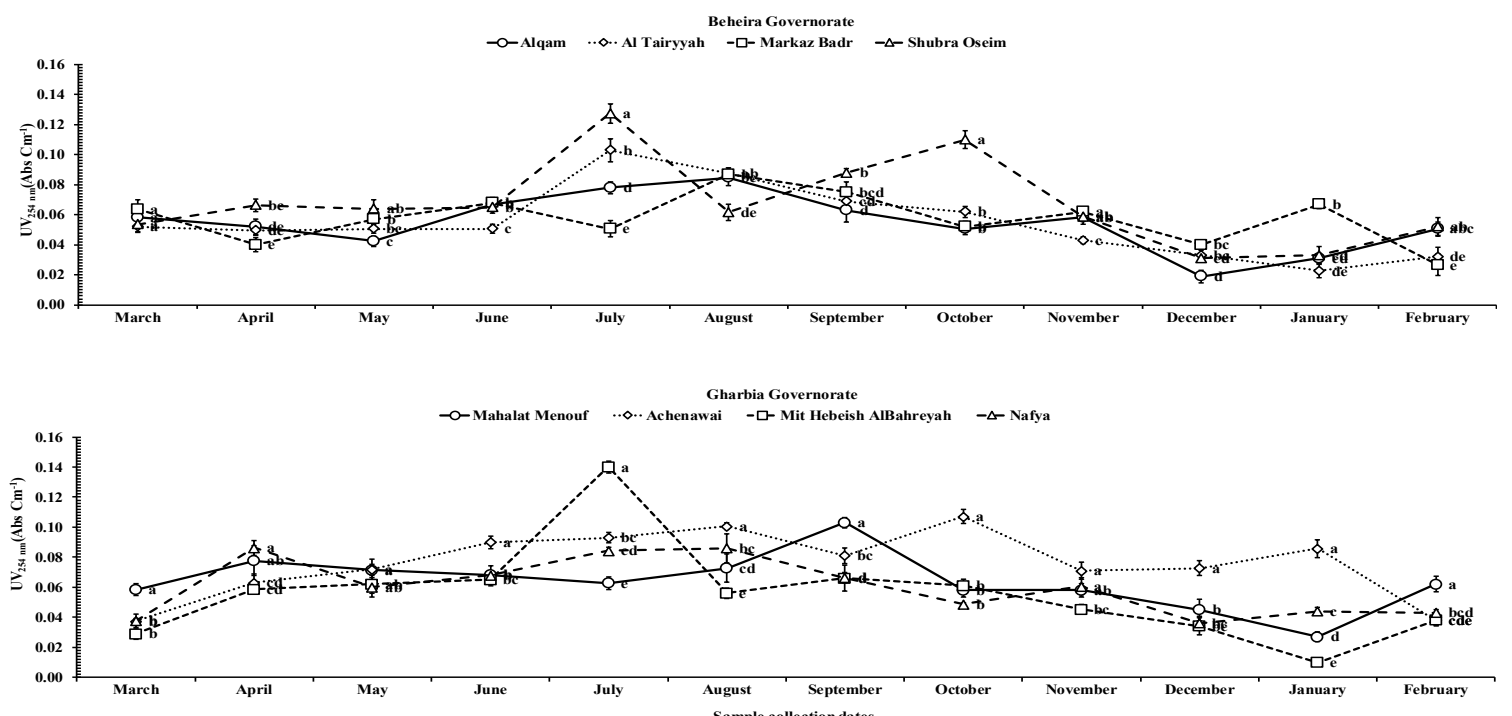

B

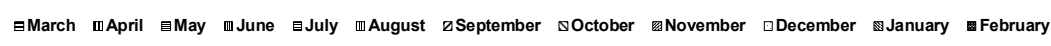

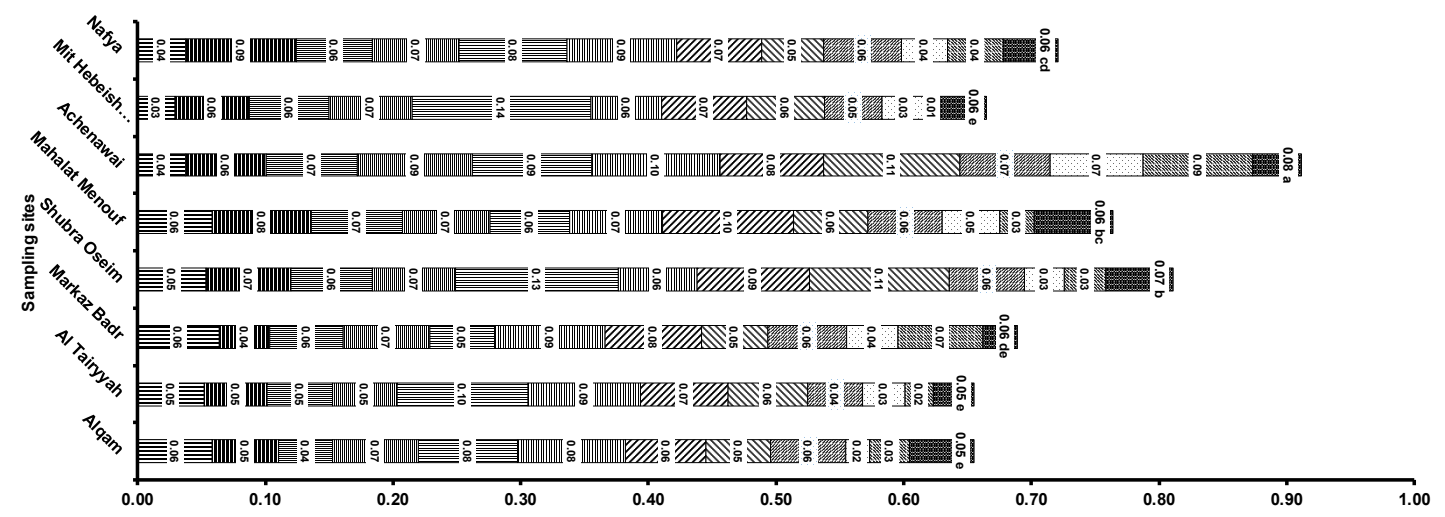

C

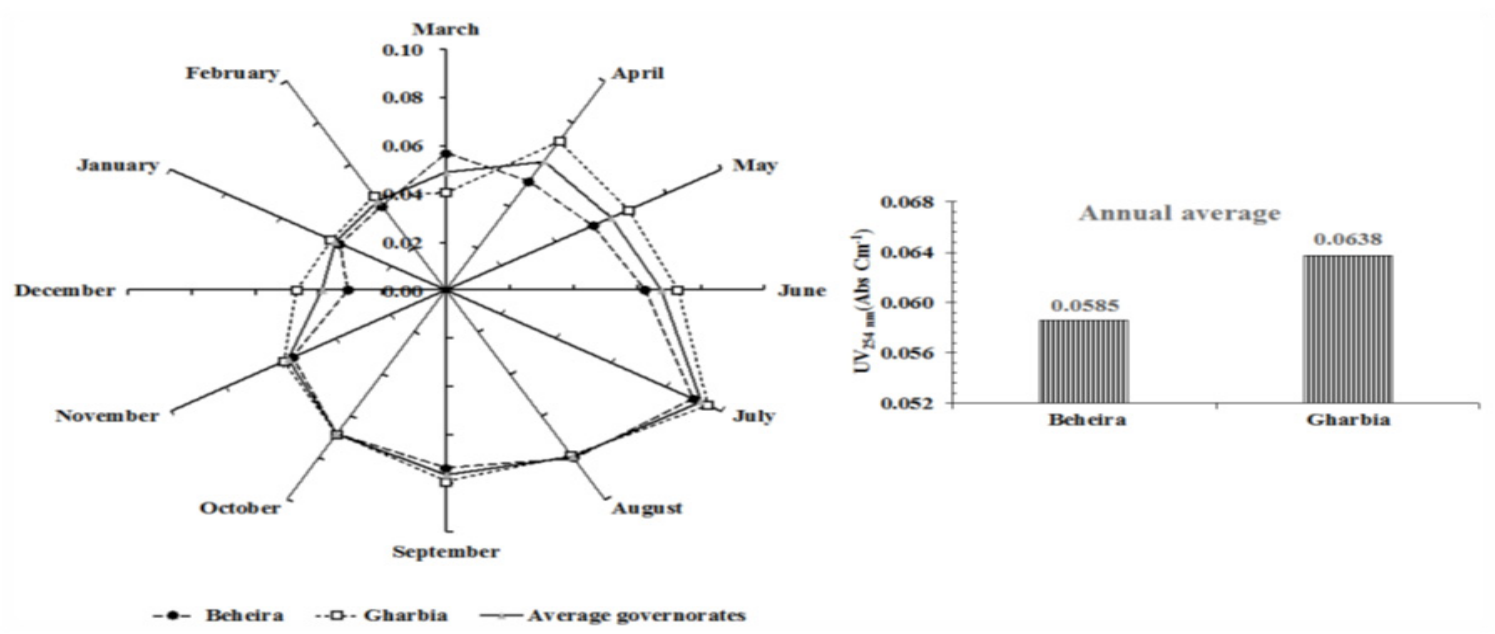

Fig. 10. $\mathrm{UV}_{254}$ absorbance values $\left(\mathrm{Abs} \mathrm{cm}^{-1}\right)$ at investigated sites in the west and middle delta regions (A: Site monthly average; $B$ : site average and the cumulative value of water parameter and $C$ : region monthly averages and the annual averages). 
January and February (0.039, 0.040 and 0.043, respectively). Achenawai site recorded the highest value (0.076), while, Alqam and $\mathrm{Al}$ Tairyyah sites recorded the lowest values $(0.055$, 0.055 , respectively). The annual averages of the two governorates were converging (with 0.064 and 0.059 for Gharbia and Beheira governorates, respectively). Monthly values were more variable in Gharbia than Beheira.

Chemical oxygen demand (COD) is a measure of the amount of oxygen equivalent consumed by the oxidation of chemicals, whether organic or inorganic by a strong chemical oxidizing agent in an acidic medium. While, Biological oxygen demand (BOD)is the measure of the oxygen required by microorganisms whilst organic matter decomposition for a particular time (generally 5 days) under aerobic conditions (Moussa, 2003). And so, on both are a factual measure of contamination, which is an environmental serious dilemma. COD analysis needs 3-4 hours to estimate organic matter, rather than the five days required by the $\mathrm{BOD}$ test, and it can be used to predict BOD. The BOD/COD ratio is typically 0.5 for the most samples. So, COD can be used as an alternative to BOD to determine water chemical pollution. The values of COD (Table 4 and Fig. 11) show that most values exceed the maximum permissible limit of guidelines adopted in this study (all except one measurement Alqam/ December). There were differences among COD measurements, where the values ranged between 9.09: $40.61 \mathrm{mg} \mathrm{L}^{-1}$, the maximum monthly values recorded in July (29.33 $\mathrm{mg} \mathrm{OL}^{-1}$ ) while the lowest values were recorded in December $(13.98 \mathrm{mg}$ $\left.\mathrm{OL}^{-1}\right)$. The highest value of COD recorded at Achenawai site $\left(23.45 \mathrm{mg} \mathrm{OL}^{-1}\right)$ while the lowest one recorded in Markaz Badr site (17.9 mg O $\left.\mathrm{L}^{-1}\right)$. There was a convergence between the annual average of the two governorates (20.8 and 19.47 $\mathrm{mg} \mathrm{OL}^{-1}$ for Gharbia and Beheira, respectively).

In general, the water quality decreases (the rate of pollution increases) in the summer months and reaches its lowest level in August month and then starts to rise to reach its highest level in January. On the other hand, Achenawai is the most polluted sites (least in water quality) at all sites, also the most polluted site in Gharbia and the most polluted sites in Beheira is Shubra Oseim. While Mahalat Menouf and Al Tairyyah were the lest polluted sites ever. The values of all studied parameters in Gharbia exceeded those in the Beheira governorate except for turbidity.
Thus, the studied sites in Gharbia are considered to be less water quality than those in Beheira governorate and are more polluted (Fig. 12).

\section{Discussion}

From the previous data, we can conclude that $\mathrm{pH}$ value and $\mathrm{Cl}^{-}$ion content elevated in December (winter season) and decline at hot months. $\mathrm{pH}$ value was always on the alkaline side and had low convergent. Chloride content in water indicates existence an organic waste principally of animal origin (Thresh et al., 1949). The elevated $\mathrm{pH}$ values may be attributed to the increased denitrification $\left(\mathrm{NO}_{2}^{-} \rightarrow \mathrm{NO}_{3}^{-} \rightarrow \mathrm{NH}_{3}^{+}\right)$in water, under the anaerobic conditions, which resulted from the decomposition and death of phytoplankton, under the low winter temperatures. Respectively, it has been suggested that the higher $\mathrm{Cl}^{-}$conc. during low flow, conditions can be attributed to wastes quantity stability, special municipal and sewage with lack of water flow in December and winter months in general. Also, more sewage resulted in more $\mathrm{NH}_{3}^{+}$concentration and more decline in $\mathrm{pH}$ values (Shabana 1999).

EC values were also elevated in September (the hot months) and decline in May month (spring month). This may attribute to the increase in the evaporation rate, where the temperature impacts the rate of rock chemical weathering (Wetzel 1983). The value of EC is related to water inorganic pollution. So, the decline of EC values may attribute to declining nutrients leaches in this period (Fertilization is not practiced in this period). The maximum values of TDS and TS recorded in July, while the minimum values recorded in March. This may be due to the increase in water temperature, which increases evapotranspiration (Mohamed and Abdel-Satar 2005). This increase the inorganic portion and the increase of phytoplankton growth responsible for the organic matter part of TS.

It is noted that Color, COD, and $\mathrm{UV}_{254}$ values increased through the hot months compared with the cold months $(11,12,1$, and 2). This may be attributed to the growth of phytoplankton and the increase in photosynthesis with high temperature. Whereas, phytoplankton was a major contributor to the organic matter in the watercourse. High water and air temperatures also increase the rate of organic matter decomposition (Abdo 2002; Elewa et al. 2007). Resulting in an increase in the value of $\mathrm{UV}_{254}$ absorption, which is associated with 
A

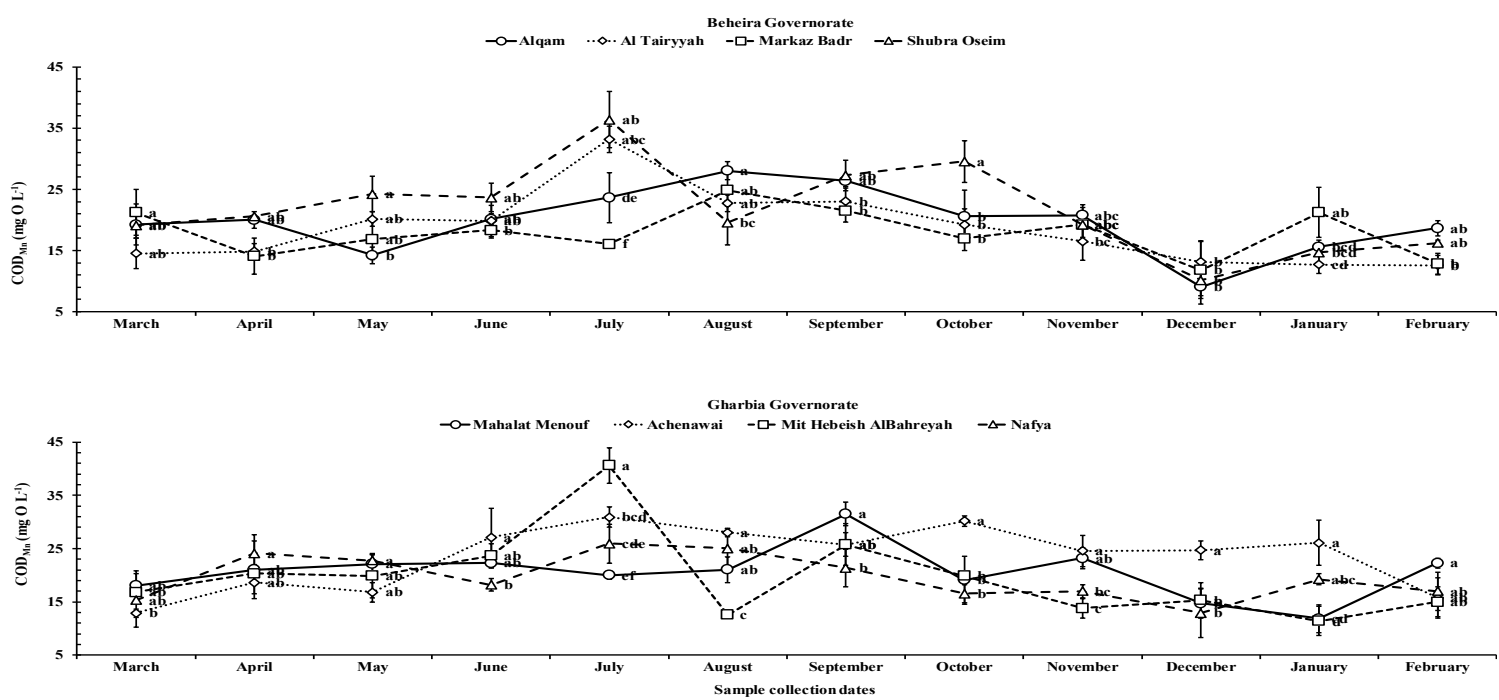

B

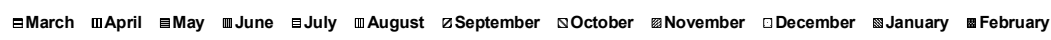

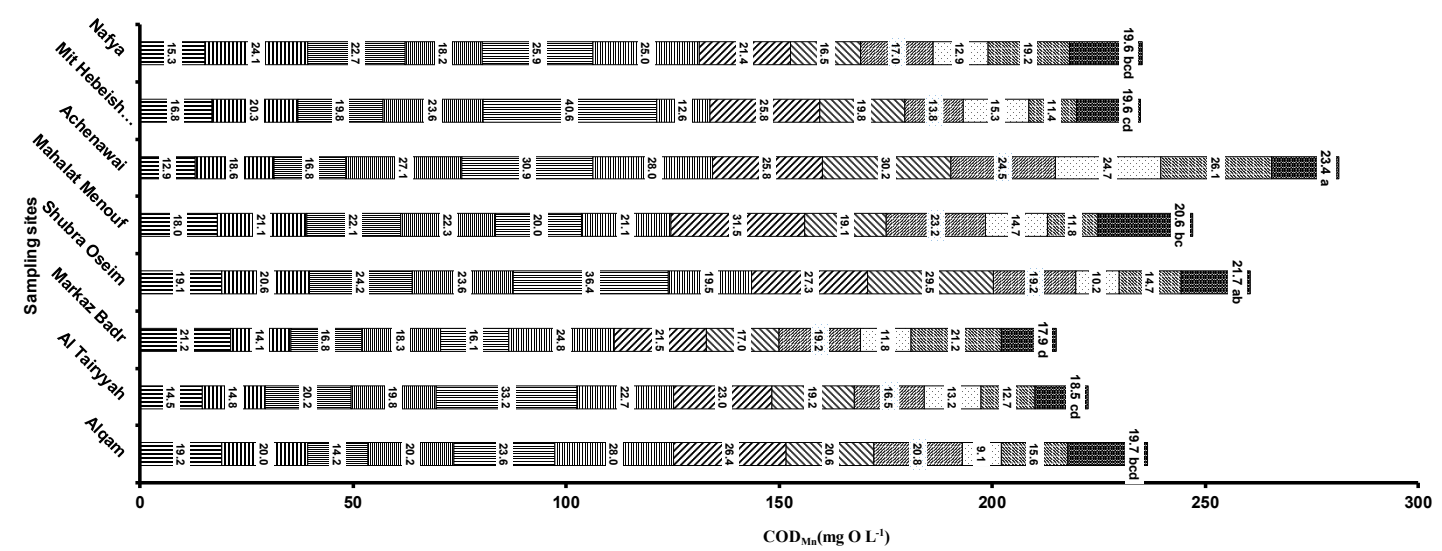

C
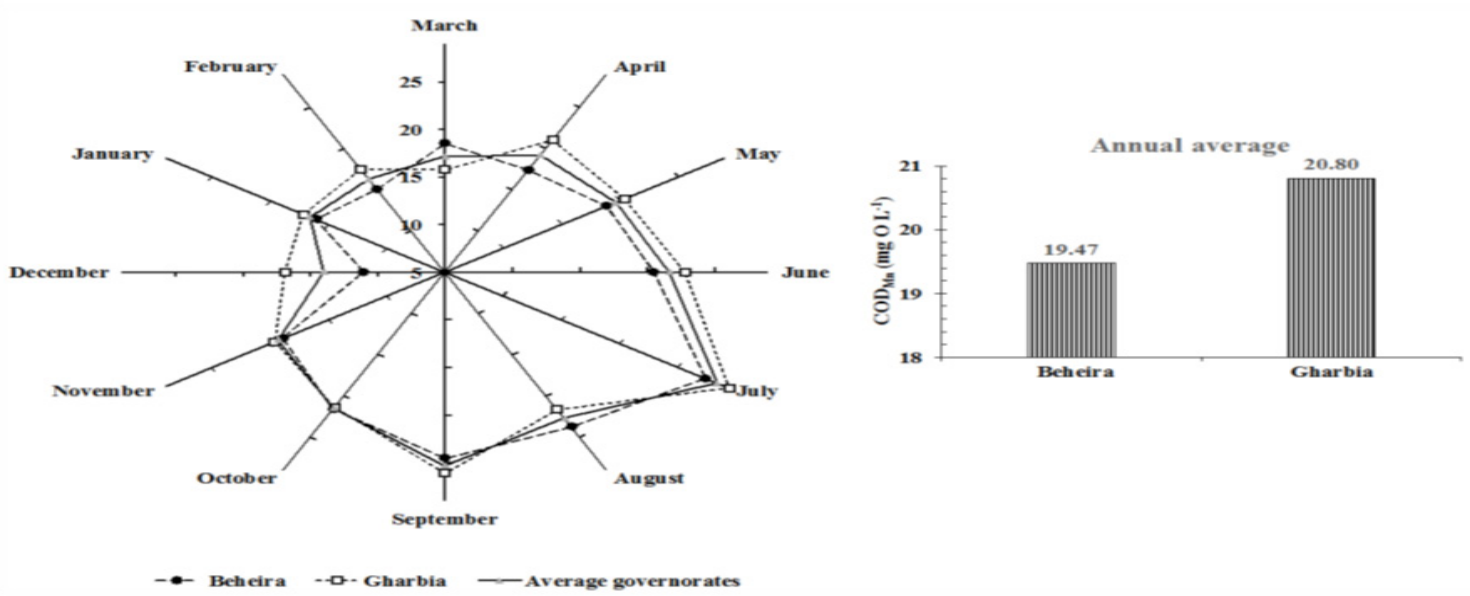

Fig. 11. COD mg OL $\mathrm{OL}^{-1}$ Values at investigated sites in the west and middle delta regions (A: Site monthly average; $B$ : site average and the cumulative value of water parameter and $C$ : region monthly averages and the annual averages). 
A

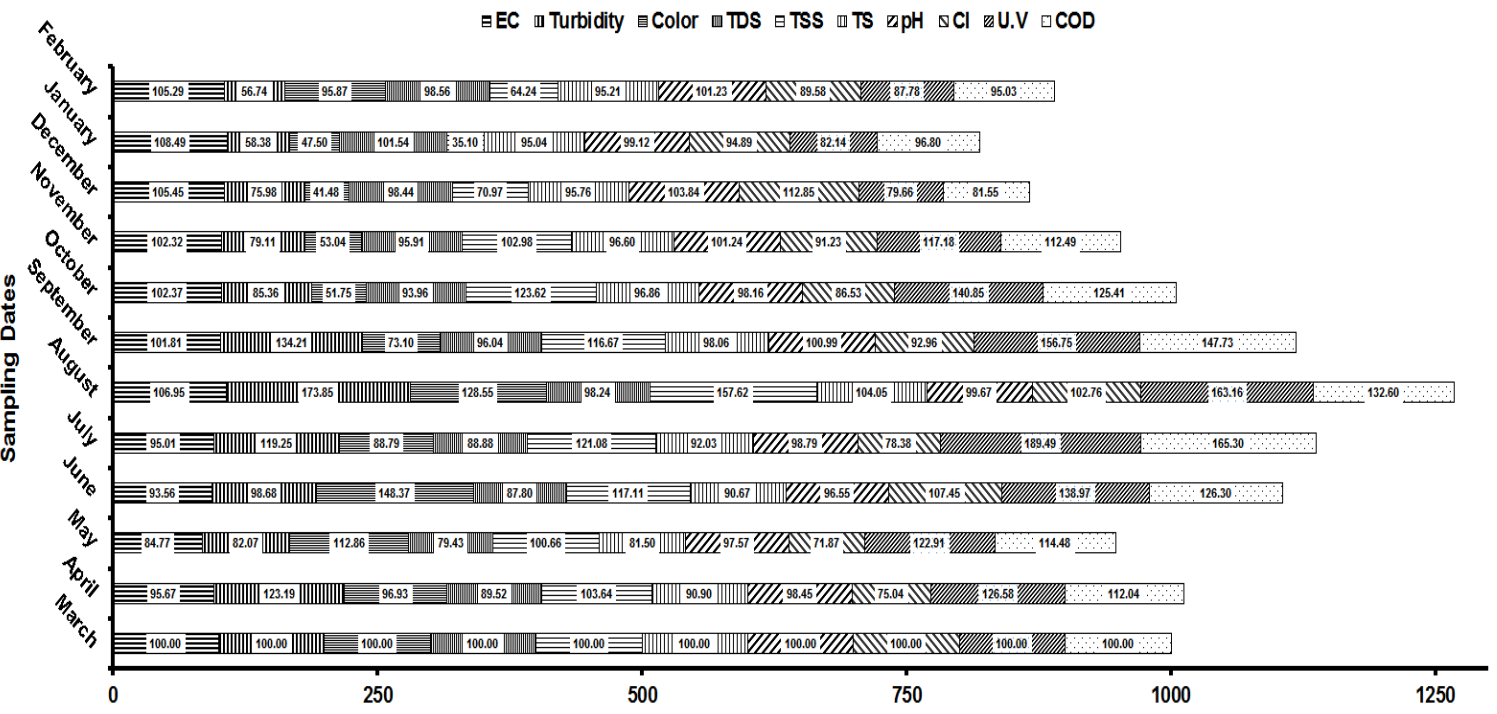

B

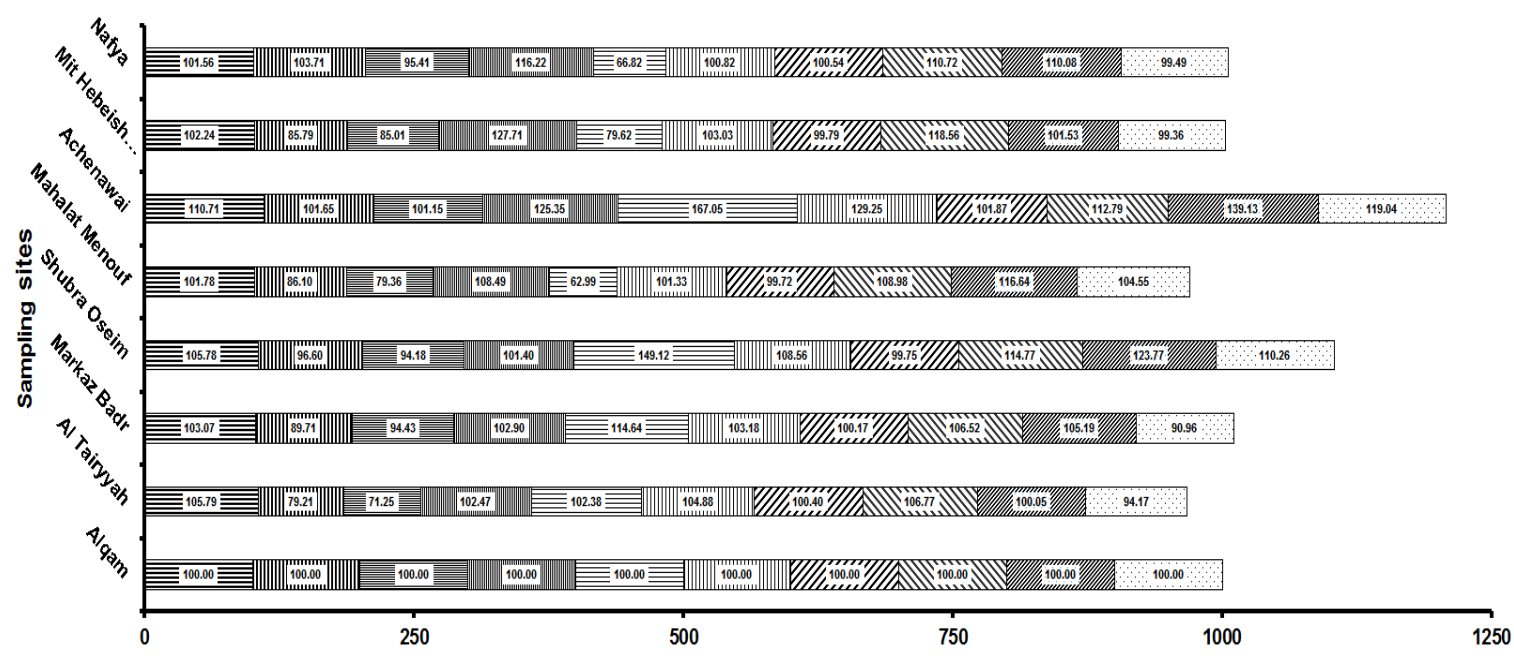

C

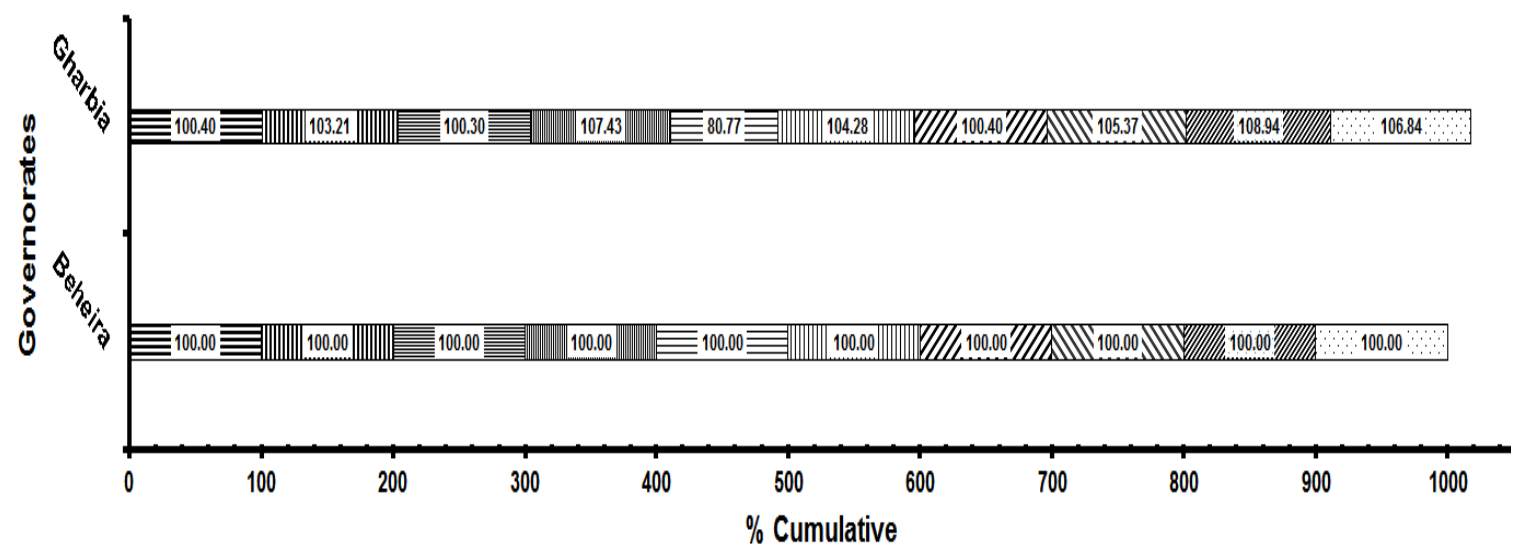

Fig. 12. Cumulative percentage of the studied parameter at investigated sites in the west and middle delta regions (A: Site annual average; B: Sample site average C: Governorate annual averages).

Env. Biodiv. Soil Security Vol. 3 (2019) 
the amount of organic matter in water and also increases color value due to increased chlorophyll conc. in water associated with the increase of phytoplankton biomass (Ogawa 1990).

But there are other sources of pollution in the watercourses. Owing to industrial and agricultural activities huge amounts of untreated urban municipal, industrial wastewater and rural domestic wastes discharge into the canals or agricultural drains (Stahl et al. 2009). Also, the excessive use of water and chemical fertilizer leads to nutrient leaching to agricultural drains. Which directly pour into different irrigation channels without purification. Which increases the concentration of nutrients (especially nitrogen and phosphate) in the water of irrigation channels, which improve phytoplankton growth, especially with the availability of the appropriate climate. This is in addition to the problem of Sewage. In our studied region, untreated sewage wastes are discharged into drains and canals (in officially or unofficially manner).

As we mentioned earlier in the material and methods (Table 2). There is a difference in soil type between the two studied regions. Gharbia characterized by clay soil, while the soil texture in most areas of Beheira is sandy soil (except for Shubra Oseim). Soil texture has a significant role in the leaches of nutrients into the different watercourses, both groundwater, and surface. Sandy soils have low water and cation/anion holding capacity and are thus apt to leach (Shepherd and Bennett 1998). The rate and the total amount of leached ions influenced by many other factors, including soil nutrient exchange capacity, the total amount of irrigated water, rate and form of fertilizer, solubility, and ion adsorption and the presence of associated ions (Havlin et al. 1999).

The main source of water for both regions is Rasheed branch, which receives more than 3 million cubic meters daily of untreated or partially treated domestic and industrial wastes and in addition to agricultural drainage water (El Gammal and El Shazely, 2008). In order to satisfy the water demands of the Western Delta irrigation improvement project, the water of many drains (El-Rahawy, El-Nasr-3, El-Umoum, Tharwat, Abu-Almatamir, Edko, and Zarkon drains) are discharged directly to Western Delta Canals, which impact the water quality (Agrama and ElSayed 2013). According to the previous reasons (water reuse, sandy soil, agricultural crops with high fertilizer requirements and excessive use of agrochemicals), water quality in the Beheira regions is supposed to be lower than that in the Gharbia regions. However, the results obtained confirm that the water quality of in Beheira is better than that in the Gharbia governorate. This may be due to the use of sprinkler and drip irrigation whereas; the only region using surface irrigation Shubra Oseim had the lowest water quality in Beheira. Drip irrigation system reduces overland flow, in contrast, surface irrigation increases the runoff and the leaches of nutrients into watercourses. That polluted the surface and groundwater resources (Damodhara 2013)

\section{Conclusion}

The studied water canals in the west and middle delta regions of Beheira and Gharbia suffer from organic pollution where the values of $\mathrm{COD}$ and $\mathrm{UV}_{254}$ have increased. Although the quality of the water according to the different guidelines used is satisfactory. It is also noticed that the level of water quality is relatively high in the region of Beheira compared with the regions of Gharbia Despite the availability of many factors that increase the pollution of the regions in the Beheira gov. in terms of soil type, cultivate crops voracious to Nutrient, overuse of agricultural chemicals, poor quality of water used in irrigation region (water mixed with large proportions of untreated agricultural drainage is used). The high water quality in the Beheira Governorate may be due to the use of spray irrigation and drip irrigation, which reduces nutrient leaching from the fields to the watercourses. Therefore, the study suggests the extensive use of spray irrigation and drip in the appropriate places after conducting the appropriate studies so that we can overcome the problem of pollution in the watercourses.

\section{Acknowledgment}

I would like to express my utmost respect and appreciation to all employees and sponsors on "The research fund Tanta University" to their great support to produce this search. Where, this research funded by the research fund Tanta University in the framework of the research project" Solar photo-catalytic degradation of environmental contaminants" (under code: TU01-13-08).

\section{References}

Abdel-Satar A. M., M. H. Ali and M. E. Goher (2017) 
Indices of water quality and metal pollution of Nile River, Egypt. Egyptian Journal of Aquatic Research 43, 21-29. http: //dx.doi.org/10.1016/j. ejar.2016.12.006

Abdo M. (2002) Environmental studies on Rosetta branch and some chemical applications at the area extend from El-Kanater El-Khyria to Kafr-El-Zyat City. Ph.D. Thesis, Fac. Sci., Ain Shams Univ. Cairo, Egypt.

Agrama A. and E. El-Sayed (2013). Assessing and mapping water quality (case study: Western DeltaEgypt). Int Water Technol J. 3 (3): 158-169.

APHA (1999). Standard Methods for the Examination of Wastewater. 20 $0^{\text {th }}$ edition, America Public Health Association, Washington, DC, USA.

Ayers R. and D. Westcot (1994). Food, Agriculture Organization of the United Nations (FAO), Water Quality for Agriculture. Irrigation and Drainage, Rome, Paper. 29.

Ayers R. S. (1975). Quality of water for irrigation. Proc. Irrig. Proc. Irrig. Drain Div., Especially Conf., Logan, Utah, Am. Soc. Civ. Eng., 24-56.

Bahr C., J. Schumacher, M. Ernst, F. Luck, B. Heinzmann and M. Jekel (2007). SUVA as control parameter for the effective ozonation of organic pollutants in secondary effluent. Water Science and Technology. 55 (12): 267-274.

Campbell J. and S. Wildberger (1992). The monitor's handbook. Chestertown MD: LaMotte Company, $30-2,36-9$.

CAPMAS (Central Agency for Public Mobilization and Statistics), (2017). Egypt in Figures. https: //www. capmas.gov.eg/ (Accessed 29 December 2017)

CCME (Canadian Council of Ministers of the Environment) (2007). Canadian environmental quality guidelines, 1999. For the protection of aquatic life 2007. Canadian Council of Ministers of the Environment, Winnipeg.

Cuthbert I. D. and P. del Giorgio (1992). Toward a standard method of measuring color in freshwater. Limnology and Oceanography. 37 (6): 1319-1326.

Das R., N. R. Samal, P. K. Roy and D. Mitra (2006). Role of electrical conductivity as an indicator of pollution in shallow lakes. Asian Journal of Water, Environment, and Pollution. 3, (1): 143-146.

DRI (2010). Real-time water quality monitoring along the Nile River, Technical report of project of an environmental security and water resources management system using real-time water quality warning. El Kanater Egypt: Drainage Research Institute: $96 \mathrm{pp}$.

DWAF (1996). Africa water quality Guidelines. 7: Aquatic Ecosystems, 1 st Ed. Department of Water Affairs and Forestry, Pretoria.

Egyptian Ministry of Health (2007). Egyptian drinking water quality standards. Decision number (458).

El Gammal H. A. and S. H. El Shazely (2008). Water quality management scenarios in Rosetta River Nile branch, Egypt. $12^{\text {th }}$ International Water Technology Conference Alex., Egypt, 901-912.

El Shakour E. H. A. and A. Mostafa (2012). Water quality assessment of river Nile at Rosetta branch: Impact of drains discharge. Middle-East Journal of Scientific Research. 12, (4): 413-423.

Elewa A. A., E. A. Saad, M. B. Shehata and M. H. Ghallab (2007). Studies on the effect of drain effluents on the water quality of Lake Manzala. Egyptian Journal of Aquatic Biology and Fisheries. 11 (2): 65-78.

FAO (2017). AQUASTAT Database [WWW Document]. Food Agric. Organ., Rome. URL. http: //www.fao.org/nr/water/aquastat/data/query/index. html?lang $1 / 4$ en. (Accessed 29 September 2017)

Goodner K. L. (2009). Estimating turbidity (NTU) from absorption data. Synergy Inspiring Taste, Sensus Technical Note (SEN-TN-0010). 1-3.

Havlin J. L., J. D. Beaton, S. L. Tisdale and W. L. Nelson (1999). Soil Fertility and Fertilizers: An Introduction to Nutrient Management. $6^{\text {th }}$ ed., Prentice Hall, Upper Saddle River, NJ.

Jiang S. and H. Zheng (2009). Study on the determination of permanganate index by UV-Vis spectrometry. Spectroscopy and Spectral Analysis. 29 (8): 2227-2231.

Mailapalli, D. R., N. S. Raghuwanshi and R. Singh (2013). Sediment Transport Model for a Surface Irrigation System. Applied and Environmental Soil Science. 2013, 10.https: //doi. org/10.1155/2013/957956.

Mohamed H. H. A. and A. M. Abdel-Satar (2005). Studies of some heavy metals in water, sediment, fish and fish diets in some fish farms in El-Fayoum province, Egypt. Egypt. Egyptian Journal of Aquatic Research. 31 (2): 261-273.

Env. Biodiv. Soil Security Vol. 3 (2019) 
Moussa M. (2003). Studies on some biological and biochemical aspects of freshwater snails in Ismailia Governorate. Ph.D. Thesis, Zoology department. Faculty of Science, Suez Canal University.

Negm A. M. (2019). Conventional Water Resources and Agriculture in Egypt. The Handbook of Environmental Chemistry Series, Springer International Publishing $\mathrm{AG}$, part of Springer Nature, https: //doi.org/10.1007/978-3-319-95065$\underline{5}$

Nkansah M. A., J. Ofosuah and S. Boakye (2011). Quality of groundwater in the Kwahu West district of Ghana. Environmental Research Journal. 5, (2): 31-37.

Ogawa H. (1990). Source and behavior of organic carbon of seawater in Tokyo Bay. Geochemistry. 24, 27-41.

Omran E.-S.E. (2017). Land and groundwater resources in the Egypt's Nile Valley, Delta, and its fringes. In: A.M. Negm (ed.), Groundwater in the Nile Delta, HdbEnvChem, DOI 10.1007/698 2017 64, Springer International Publishing AG

Owusu-Boateng G. and E. Kumi-Aboagye (2013). An assessment of the status of pollution of the Lake Amponsah in the Bibiani-Anhwiaso-Bekwai District, Ghana. American Journal of Scientific and Industrial Research. 4 (5): 499-511

Paustian P. (1986). A novel method to calculate the Mohr chloride titration. Water Analysis and Treatment, Proceedings of the $14^{\text {th }}$ Annual American Water Works Association Water Quality Technology Conference, Portland, Ore, American water works association., Denver, Co., 673.

Rahman M. M., M. Verdegem, L. Nagelkerke, M. A. Wahab, A. Milstein and J. Verreth (2008). Effects of common carp Cyprinuscarpio (L.) and feed addition in rohuLabeorohita (Hamilton) ponds on nutrient partitioning among fish, plankton and benthos. Aquaculture Research. 39 (1): 85-95.

Salem Z. E., A. ElNahrawy and M. Ghobara (2019). Spatiotemporal Hydrochemical Evaluation and Quality Assessment of Drainage Water Compared to Canal Surface Water in the Middle Nile Delta, Egypt. In: A. M. Negm (ed.), Unconventional Water Resources and Agriculture in Egypt, HdbEnvChem 75: 123-162, DOI 10.1007/698_2018_296, Springer International Publishing AG

Salman S. A., M. Arauzo and A. A. Elnazer (2019). Groundwater quality and vulnerability assessment in west Luxor Governorate, Egypt. Groundwater for Sustainable Development 8: 271-280. https: // doi.org/10.1016/j.gsd.2018.11.009

Shabana, E. E. (1999). Limnological studies on Lake Bardawil. M. Sc. Thesis, Faculty of Science, Suez Canal University. Egypt.

Shepherd M. A. and G. Bennett (1998). Nutrient leaching losses from a sandy soil in lysimeters. Communications in Soil Science and Plant Analysis. 29 (7-8): 931-946.

Siliem T. A. E. (1995). Primary productivity of the Nile in barrage area. Menofiya Journal of Agricultural Research. 20 (4): 1687-1701.

Stahl R., A. B. Ramadan and M. Pimpl (2009). Bahr El-Baqar drain system/Egypt environmental studies on water quality. Part I: Bilbeis drain/Bahr ElBaqar drain. Forschungszentrum Karlsruhe in der Helmholtz-GemeinschaftWissenschaftlicheBerich te FZKA 7505, 72.

Thresh J. C., J. F. Beale and E. V. Suckling (1949). The examination of water and water supplies. B.W. Taylor, London.

Wagner R. J., R. W. Boulger, C. J. Oblinger and B. A. Smith (2006). Guidelines and standard procedures for continuous water-quality monitors: Station operation, record computation, and data reporting. U.S. Geological Survey Techniques and Methods, 1-D3: 51.

Wahba S M., K Scott, J K. Steinberger (2018). Analyzing Egypt's water footprint based on trade balance and expenditure inequality. Journal of Cleaner Production 198: 1526-1535. https: //doi. org/10.1016/j.jclepro.2018.06.266

Wetzel R. G. (1983). Limnology. $2^{\text {nd }}$ ed., Saunders College Publishing Philadelphia. 767.

Wetzel R. G. and G. E. Likens (1991). Limnological analysis. $2^{\underline{\underline{n d}}}$ ed, Springer-Verlag, New York. 391.

WHO (2011). Guidelines for Drinking-water Quality. $4^{\text {th }}, 38,4: 104-108$.

Yang W., J. Nan and D. Sun (2008). An online water quality monitoring and management system developed for the Liming River basin in Daqing, China. Journal of Environmental Management. 88, (2): 318-325.

(Received 3/4/2019; accepted 17/4/2019)

Env. Biodiv. Soil Security Vol. 3 (2019) 